\title{
The Na/K-ATPase Signaling and SGLT2 Inhibitor-Mediated Cardiorenal Protection: A Crossed Road?
}

\author{
Jiang Liu ${ }^{1} \cdot$ Jiang Tian $^{1} \cdot$ Komal Sodhi $^{2} \cdot$ Joseph I. Shapiro ${ }^{3}$
}

Received: 31 March 2021 / Accepted: 6 July 2021 / Published online: 23 July 2021

(c) The Author(s) 2021

\begin{abstract}
In different large-scale clinic outcome trials, sodium $\left(\mathrm{Na}^{+}\right) /$glucose co-transporter 2 (SGLT2) inhibitors showed profound cardiac- and renal-protective effects, making them revolutionary treatments for heart failure and kidney disease. Different theories are proposed according to the emerging protective effects other than the original purpose of glucose-lowering in diabetic patients. As the ATP-dependent primary ion transporter providing the $\mathrm{Na}^{+}$gradient to drive other $\mathrm{Na}^{+}$-dependent transporters, the possible role of the sodium-potassium adenosine triphosphatase ( $\mathrm{Na} / \mathrm{K}$-ATPase) as the primary ion transporter and its signaling function is not explored.
\end{abstract}

\section{Graphic Abstract}

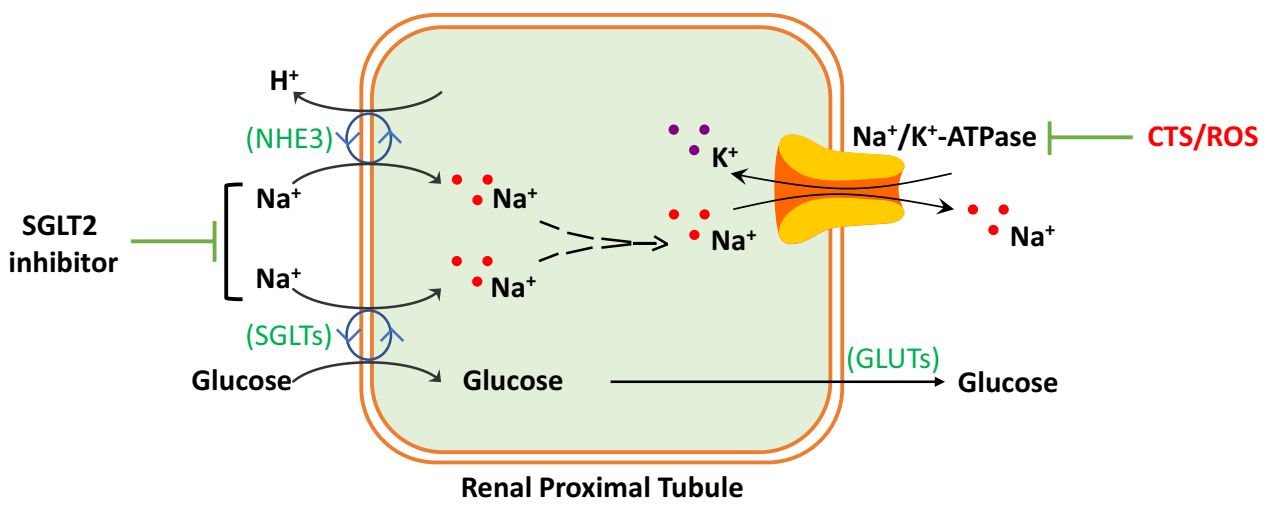

Keywords SGLT inhibitor $\cdot$ Na/K-ATPase $\cdot$ ROS $\cdot$ Signaling

\section{Introduction}

SGTL2 inhibitors were initially developed to lower plasma glucose in patients with type 2 diabetic mellitus (T2DM). More available data from completed clinical trials

Jiang Liu

liuj@marshall.edu

1 Department of Biomedical Sciences, JCE School of Medicine, Marshall University, Huntington, WV, USA

2 Department of Surgery, JCE School of Medicine, Marshall University, Huntington, WV, USA

3 Departments of Medicine, JCE School of Medicine, Marshall University, Huntington, WV, USA show profound cardiorenal protection in diabetic and nondiabetic chronic kidney disease (CKD) patients, which cannot be directly explained by improved glucose control. More and more insightful theories are proposed to explain the "offtarget" but incredible effects of SGLT2 inhibitors other than the designed glucose-lowering property initially, as reviewed in more detail elsewhere. The molecular mechanism(s) to delineate the cardiorenal protection of SGLT2 inhibitors are still not fully understood. Based on clinical trials and experimental findings, the proposed theories include, but not limited to, the SGLT2 inhibitor-mediated regulations of (1) blood pressure through glomerular filtration rate, tubuloglomerular feedback, sodium/hydrogen $\left(\mathrm{Na}^{+} / \mathrm{H}^{+}\right)$exchangers, 
natriuresis/osmotic diuresis; (2) oxidative stress by oxygen consumption/inflammatory cytokines, as well as (3) metabolic profile alteration, growth factors, fibrotic mediators, nutrient deprivation, weight loss, ketogenesis, artery stiffness, sympathetic nervous system, and others. However, the protection of SGLT2 inhibitors could not be fully explained by a single mechanism since different clinic treatment strategies targeting different conditions are short of the overall effect of the SGLT2 inhibitors. The effects of the SGLT inhibitors are more likely related to their renal effects (Bertero et al. 2017; Gerich, 2010; Nikolic et al. 2021; Patel et al. 2021; Santos et al. 2020; Sen and Heerspink, 2021; Thomson and Vallon 2019), and an interplay of modest beneficial effects from different systems. Besides more available data from clinical trials, experiments of molecular mechanisms are much more desired. With mounting evidence of mechanisms and theories, the involvement of the $\mathrm{Na} / \mathrm{K}$ ATPase is only described as an active $\mathrm{Na}^{+} / \mathrm{K}^{+}$transporter to maintain the $\mathrm{Na}^{+}$gradient across the membrane, functioning as a driving force for $\mathrm{Na}^{+}$and glucose reabsorption. The $\mathrm{Na} / \mathrm{K}$-ATPase also acts as a signaling transducer (coupling with tyrosine kinase c-Src) to execute different functions. This review explores the possible role of $\mathrm{Na} / \mathrm{K}$-ATPase and its signaling function that might affect SGLT2 and SGLT2 inhibitors.

\section{The Biology of the Na/K-ATPase}

The Na/K-ATPase belongs to the P-type ATPase family and consists of two non-covalently linked $\alpha$ and $\beta$ subunits. Several $\alpha$ and $\beta$ isoforms, expressed in a tissue-specific manner, have been identified and functionally characterized (Blanco and Mercer 1998; Kaplan 2002; Sanchez et al. 2006; Sweadner 1989). Since J.C. Skou's discovery in 1957 (Skou 1957), the energy-transducing Na/K-ATPase has been extensively studied for its ion pumping function and, later on, its signaling role (Aizman and Aperia 2003; Shapiro and Tian 2011; Xie and Cai 2003; Zhang et al. 2019a). Cardiotonic steroids (CTS, also known as digitalis-like substances) are specific $\mathrm{Na} / \mathrm{K}-\mathrm{ATPa}$ e inhibitors and ligands. CTS has been used to treat heart failure for over 200 years through its inotropic effect due to partial inhibition of Na/K-ATPase induced intracellular $\mathrm{Na}^{+}$change coupled with increases in intracellular calcium $\left(\mathrm{Ca}^{2+}\right)$ through $\mathrm{Na}^{+} / \mathrm{Ca}^{2+}$ exchanger (NCX). CTS also stimulates the signaling function of the $\mathrm{Na} / \mathrm{K}$-ATPase, which has been contributed to cardiac hypertrophy and fibrosis, $\mathrm{Na}^{+}$reabsorption in renal proximal tubule cells (RPTs), systemic oxidative stress, and release of inflammatory cytokines. "The third factor" or "natriuretic factor", other than glomerular filtration rate and aldosterone, was postulated to regulate renal $\mathrm{Na}^{+}$handling through $\mathrm{Na}$ /K-ATPase (Bricker 1967; Dahl et al. 1969; de Wardener and MacGregor 1980). Identification of ouabain-like substance in human plasma and in vivo studies with genetically modified mouse models (humanized ouabain-sensitive $\mathrm{Na} / \mathrm{K}-\mathrm{ATPa} e \mathrm{\alpha} 1$ ) have unequivocally demonstrated that endogenous CTS regulates renal $\mathrm{Na}^{+}$excretion and blood pressure through the Na/K-ATPase (Dostanic-Larson et al. 2005; Dostanic et al. 2005; Hamlyn et al. 1991; Loreaux et al. 2008).

CTS has been classified as a new class of hormones, making $\mathrm{Na} / \mathrm{K}$-ATPase a potential therapeutic target for cardiac and renal diseases (Aperia 2007; Bagrov and Shapiro, 2008; Bagrov et al. 2009; Schoner 2002; Yatime et al. 2009). CTS includes plant-derived glycosides such as digoxin and ouabain and vertebrate-derived aglycones such as bufalin and marinobufagenin. The production and secretion of ouabain and marinobufagenin can be regulated by multiple stimuli, including angiotensin II and adrenocorticotropic hormone (ACTH) (Bagrov et al. 2009; Hamlyn et al. 1991; Laredo et al. 1997; Schoner 2002; Schoner and Scheiner-Bobis 2007a, b, 2008). Endogenous CTS are present in measurable amounts under normal physiological conditions and are markedly increased under several pathological conditions such as $\mathrm{Na}^{+}$imbalance, chronic renal failure, hyperaldosteronism, hypertension, congestive heart failure, plasma volume, blood pressure, and salt sensitivity (Blaustein 1993; Fedorova et al. 1998, 2001,2002; Gottlieb et al. 1992; Hamlyn et al. 1991, 1998; Hasegawa et al. 1987; Komiyama et al. 2005; Manunta et al. 2006a,1999; Rossi et al. 1995). studies have also revealed many extra-cardiac actions, such as in response to salt loading and hypertensions (Fedorova et al. 2005; Ferrari et al. 2006; Haddy and Pamnani 1998; Kaunitz 2006; Manunta et al. 2006b). Also, low doses of CTS induced hypertension in rats and caused significant cardiovascular $(\mathrm{CV})$ remodeling independent of their effect on blood pressure (Ferrandi et al. 2004; Jiang et al. 2007; Kennedy et al. 2006; Skoumal et al. 2007).

\section{The Biology of SGLTs}

The kidney is involved in regulating glucose homeostasis (Bergman and Drury 1938) and is critical in developing and managing diabetes mellitus, including gluconeogenesis to release glucose, glucose uptake for energy supply, and glucose reabsorption (Gerich 2010). The glucose reabsorption from glomerular filtrate in RPTs is an energy-requiring process that reabsorbs $\sim 180 \mathrm{~g}$ per day through SGLTs. The SGLTs belong to a structural class of membrane proteins (Bell et al. 1990; Wright et al. 2011). In RPTs, SGLTs at the apical membrane mediate the entry of glucose, and glucose transporters (GLUTs) at the basolateral membrane mediate the extrusion of glucose into the circulation. The driving force is the energy-dependent $\mathrm{Na} / \mathrm{K}$-ATPase which 
also extrudes reabsorbed $\mathrm{Na}^{+}$into circulation. SGLT2 is a high-capacity, low-affinity transporter (co-transport $\mathrm{Na}^{+}$ and glucose at 1:1 stoichiometry) located on the $\mathrm{S} 1$ and $\mathrm{S} 2$ segments, reabsorbing 90\% filtered glucose. SGLT1 is a high-affinity, low-capacity transporter (co-transport $\mathrm{Na}^{+}$and glucose at 2:1 stoichiometry) located on the S3 segment, reabsorbing the $\sim 10 \%$ filtered glucose (unabsorbed glucose by SGLT2) (Brown 2000; Hediger and Rhoads 1994; Lee et al. 2007; Wright et al. 2007,2011). In healthy individuals with normal kidney function, urine is essentially free of glucose since all glomerular filtrated glucose is reabsorbed. Changes in glucose or $\mathrm{Na}^{+}$filtered rate modulates the glucose transporter's (SGLT1/2 and GLUT1/2) gene expression (Vestri et al. 2001). Compared with healthy individuals, T2DM patients show significantly higher SGLT2 expression and activity, glucose reabsorption, and a higher threshold for glucosuria (Rahmoune et al. 2005; Tentolouris et al. 2019).

\section{Protection Effects of SGLT2 Inhibitor on Renal Disease}

Data from CV outcome trials showed that SGLT2 inhibitors slow the progression of kidney function decline and reduce the risks of kidney outcomes in T2DM patients with preserved kidney function (Mosenzon et al. 2019; Neal et al. 2017a; Wiviott et al. 2018; Zinman et al. 2015a). In three outcome trials assessing the SGLT2 inhibitors in CKD patients with diabetic and non-diabetic CKD (CREDENCE trial with canagliflozin, DAPA-CKD trial with dapagliflozin, and SCORED trial with sotagliflozin), significant renal-protective outcomes were observed (Bhatt et al. 2020; Heerspink et al. 2020; Mosenzon et al. 2019; Neal et al. 2017a; Perkovic et al. 2019; Wiviott et al. 2018; Zinman et al. 2015a). Canagliflozin and dapagliflozin significantly reduced the risk of kidney failure and CV events. However, there is no significant effect in the SCORED trial, probably because of the trial's early ending. Notably, the DAPA-CKD trial demonstrated that dapagliflozin reduces the risks of major adverse kidney and CV events and all-cause mortality in diabetic and non-diabetic CKD patients with or without T2DM (Heerspink et al. 2020; Wheeler et al. 2021). In the CREDENCE trial, canagliflozin treatment reduces the risk of anemia, an independent predictor of renal and CV outcomes (Oshima et al. 2020). Furthermore, canagliflozin reduces $\mathrm{CV}$ events in patients with T2DM and diabetic kidney disease (DKD) and slows DKD progression. SGLT2 inhibitors also reduce the risk of new-onset diabetic nephropathy, slow the rate of kidney function decline, and reduced the risk of major kidney events (Heerspink et al. 2020; Neal et al. 2017a; Wanner et al. 2016). In patients with heart failure and reduced ejection fraction with and without T2DM, the DAPA-HF trial (Dapagliflozin and Prevention of Adverse Outcomes in Heart Failure) demonstrated that the SGLT2 inhibitor reduces the risk of heart failure hospitalizations or CV death and slow the progression of kidney function decline (Jhund et al. 2021; Packer et al. 2020). In the DAPA-HF trial, the SGLT2 inhibitor-mediated decrease in eGFR and increase in hematocrit are more likely independent of glycemia in people with and without diabetes (Lopaschuk and Verma 2020). SGLT2 inhibitor mediated a modest increase in hematocrit that can be explained by volume depletion and increased erythropoietin production (Mazer et al. 2020; Zinman et al. 2015b).

SGLT2 inhibitors usually cause weight loss in diabetic patients, mainly due to increased natriuretic/osmotic diuresis in the early treatment. However, the permanent loss of extracellular water does not occur under SGLT2 inhibition. In the long term, it mainly involves the glycosuria-causednegative caloric balance mediated reduction of visceral/subcutaneous fat and epicardial fat mass accompanying reduced inflammatory cytokine production (Filippatos et al. 2019; Vallon and Thomson 2017). Furthermore, SGLT2 inhibition also has hepatoprotective effects by reducing fatty liver content and improve liver biology in patients with T2DM and non-alcoholic fatty liver disease (Scheen 2019; Schork et al. 2019). A metabolic shift might contribute to improving the cardiometabolic risks in T2DM patients.

Hypertension is a significant risk factor for progressive kidney function loss. SGLT2 inhibitors exert antihypertensive effects on both systolic and diastolic blood pressure without inducing a compensatory increase in heart rate (Shaikh 2017; Tikkanen et al. 2016). This phenomenon is attributed to a decrease of $30 \%$ to $60 \%$ in $\mathrm{Na}^{+}$reabsorption in PRTs, improved natriuresis and diuresis, weight loss, and improved vascular function (Lopaschuk and Verma 2020; Nikolic et al. 2021). Again, the blood-pressure-lowering effects of SGLT2 inhibition are modest and cannot fully explain the beneficial CV and kidney effects.

In the CREDENCE trial, SGLT2 inhibitor canagliflozin reduces blood pressure independent of starting blood pressure levels and other concomitant blood pressure-lowering agents in patients with T2DM and CKD (Ye et al. 2021). In the DAPASALT Trial with standardized sodium diet control in T2DM patients and preserved kidney function, dapagliflozin reduced blood pressure without apparent changes in urinary $\mathrm{Na}^{+}$excretion, natriuresis, and plasma volume within the period of the 2 -week treatment. Interestingly, a significant increase in fractional lithium excretion was observed, indicating an increase in RPTs-mediated $\mathrm{Na}^{+}$ excretion that could be counteracted by a downstream compensatory mechanism (Scholtes et al. 2021). 


\section{Protection Effects of SGLT2 Inhibitor on Cardiovascular Disease (CVD)}

Inhibition of SGLT2 has been shown to improve CV outcomes in patients with diabetic kidney disease and patients without diabetics. The EMPA-REG OUTCOME study (Zinman et al. 2015c) was the first clinical trial to mark success for secondary and tertiary CVD prevention with an SGLT2 inhibitor. The study found that empagliflozin was associated with a significant reduction in mortality, heart failure hospitalization, and kidney disease progression. It was found no significant difference in the risk of stroke with empagliflozin versus placebo. Results from the CANVAS trial further substantiated the preventive effect of SGLT2 inhibitors in CV outcomes. The CANVAS study included about 10,000 patients treated with canagliflozin or placebo and followed for 3.6 years. The result showed that canagliflozin treatment resulted in a lower incidence of CV death, nonfatal myocardial infarction, nonfatal stroke, and HF hospitalization (Neal et al. 2017b). The CVD-REAL study was a large multinational program to study patients with T2DM who did not have preexisting CVD (Kosiborod et al. 2017). The study showed a 51\% lower risk of death and a 39\% lower risk of hospitalization for HF in patients treated with empagliflozin compared to other categories of glucose-lowering drugs. It is noted that the CVD-REAL study is an observational rather than a randomize-controlled clinical trial. Several other clinical studies have shown that SGLT2 inhibitors decrease blood pressure (Baker et al. 2014; Kario et al. 2018; Vasilakou et al. 2013). In a recent meta-analysis using data from 27 clinical studies with over 7000 patients with diabetes or chronic kidney disease, SGLT2 inhibitors were found to reduce the risk of the composite $\mathrm{CV}$ outcome, hospitalized or fatal heart failure, and myocardial infarction. However, the analysis showed no apparent effect on stroke or CV death. It was also found that the overall risk of genital infections was increased by SGLT2 inhibition (Toyama et al. 2019). Since SGLT2 is dominantly expressed in the kidney proximal tubules, the beneficial effect of SGLT2 inhibitors on $\mathrm{CV}$ outcomes was mostly considered as a secondary effect of the renal function improvement and systematic glucose-lowering effect. The preserved effects of SGLT2 inhibitors on natriuresis and blood pressure may be a pivotal pathway to CV complications, especially heart failure (List and Whaley 2011; Sattar and McGuire 2018). SGLT2 inhibitors also improve renal hemodynamics and reduce the preload and afterload in heart failure patients (Cherney et al. 2014a, b; Hung et al. 2014). The metabolic effects such as lowering glycated hemoglobin, lipid profile change, and weight loss may also help reduce the CV risks (Desouza et al. 2015; Stark Casagrande et al. 2013;
Wilding et al. 2013; Zinman et al. 2015c). However, due to the mild and inconsistent results in glucose-lowering by SGLT2 inhibitors, the glycemic control seems not the primary driving force for reducing CV events (Duckworth et al. 2009; Toyama et al. 2019).

\section{Mechanistic Perception of SGLT2 Inhibitor and $\mathrm{Na} / \mathrm{K}$-ATPase}

The heart and kidney are inextricably and functionally linked, referred to as the cardiorenal syndrome (Ronco et al. 2008). For example, about $60 \%$ of HF patients have co-morbid CKD (Heywood et al. 2007; Hillege et al. 2006). Dapagliflozin causes volume depletion without an increase in the risk of hypoglycemia in non-diabetic patients, indicating the beneficial effects of SGLT2 inhibitors extend well beyond patients with T2DM. Secondary analyses of the EMPA-REG OUTCOME trial (Empagliflozin Cardiovascular Outcome Event Trial in Type 2 Diabetes Mellitus Patients) indicate that CV and kidney function benefits are unlikely mediated by the glucose-lowering properties of the SGLT2 inhibitors (Inzucchi et al. 2018). The cardiorenal syndrome is critical in HF management, which could be directly addressed by SGLT2-inhibitors (Fathi et al. 2020). As discussed above, the outcomes of different clinic trials show the co-existence of $\mathrm{CV}$ and renal protection, indicating the involvement of other nonglycemic pathways by SGLT2 inhibition (Bell and Yellon 2018).

Interestingly, both in vitro and in vivo mechanistic studies demonstrated some SGLT2 inhibitor-induced beneficial effects are independent of SGLT2 inhibition. Furthermore, the $\mathrm{Na} / \mathrm{K}$-ATPase and its signaling share some of the regulatory pathways by SGLT2 inhibitors, such as natriuresis, blood pressure, oxidative stress, inflammation.

\section{$\mathrm{Na}^{+}$Reabsorption and Natriuresis}

Natriuresis leads to volume contraction and decrease in blood pressure glomerular hyperfiltration. SGLT2 is responsible for $\approx 5 \%$ of $\mathrm{Na}^{+}$reabsorption in RPTs under normal conditions. Chronic hyperglycemia increases the expression and activity of SGLT2, leading to increased plasma volume and blood pressure. SGLT2 inhibition cause volume contraction, decreased blood pressure, and reduces glomerular pressure (Lytvyn et al. 2017). SGLT2 inhibition-mediated natriuresis is likely a major factor leading to cardiorenal protective effects observed with empagliflozin and canagliflozin, which appear to extend across CKD stages (Petrykiv et al. 2017). 
SGLT2 inhibitor has been shown to cause natriuresis, volume contraction, and blood pressure lowering. RPTs osmotically reabsorb $\sim 60-70 \%$ of filtered $\mathrm{Na}^{+}$back to circulation. This process includes the $\mathrm{Na}^{+}$entry through NHE3, SGLTs, and other $\mathrm{Na}^{+}$-dependent transporters located on the apical membrane, and the $\mathrm{Na}^{+}$extrusion through energy (ATP)-dependent Na/K-ATPase located on the basolateral membrane. The activity of NHE1 and NHE3 is upregulated in the settings of heart failure and T2DM (Packer 2017). SGLT2 and NHE3 are co-localized on the apical membrane of RPTs and functionally affecting each other. While SGLT2 inhibitor inhibits NHE3 activity, tubular-specific NHE3 knockout mice showed reduced SGLT2 expression and reduced natriuretic effect by SGLT2 inhibitor (Thomson and Vallon 2019). Empagliflozin causes volume contraction by increasing urinary excretion of $\mathrm{Na}^{+}$and bicarbonate in wild-type littermates, but not in non-diabetic mice with tubular-specific NHE3 knockdown. Moreover, in type 1 diabetic Akita mice, chronic empagliflozin treatment inhibits NHE3 activity by enhanced phosphorylation of NHE3 (S552/S605), indicating that NHE3 is a determinant of the natriuretic effect of empagliflozin (Onishi et al. 2020). When the type 1 diabetic Akita mice were compared with the type 1 diabetic Akita mice with tubular-specific NHE3 knockout, the NHE3 knockout mice show a battery of changes, which indicate that the absence of tubular NHE3 likely shifted $\mathrm{Na}^{+}$and glucose reabsorption from SGLT2 to SGLT1 that is likely associated with a pro-inflammatory renal signal (Onishi et al. 2019).

Glomerular hyperfiltration is a common pathway of kidney injury both in diabetic and non-diabetic settings and is associated with the progression of kidney function decline (Helal et al. 2012). Under hyperglycemic conditions, increased RPT reabsorption of glucose and $\mathrm{Na}^{+}$ causes decreased distal $\mathrm{Na}^{+}$delivery, leading to the activation of tubuloglomerular feedback (TGF) and glomerular hyperfiltration. SGLT2 inhibitors reduce hyperfiltration by inhibiting $\mathrm{Na}^{+}$reabsorption in RPTs (Cherney et al. 2014b; Heerspink et al. 2016; Wanner et al. 2018). In Akita mice (a T1DM model), SGTL2 inhibition decreases glomerular hyperfiltration (Heerspink et al. 2016; Kidokoro et al. 2019). In T2DM patients, SGLT2 inhibition reduces the estimated glomerular filtration rate (eGFR) associated with the preservation of long-term kidney function (Wanner et al. 2018). In both T1DM and T2DM patients with normal kidney function, dapagliflozin causes an acute fall in GFR accompanied by a reduction in renal blood flow and renovascular resistance (van Bommel et al. 2020).

\section{Mesangial Cells}

Diabetic kidney disease is the most common cause of chronic kidney disease and end-stage renal failure. Mesangial cells (MCs) play an important role in regulating glomerular filtration and in the development of diabetic nephropathy (Schena and Gesualdo 2005). Damage of MCs leads to mesangial expansion and contributes to glomerulosclerosis (Abrass 1995; Mason and Wahab 2003), and reduced contractile response of MCs is a known cause of hyperfiltration (Donnelly et al. 1996; Gnudi et al. 2007; Kreisberg, 1982). Expression of the Na/K-ATPase, NHEs, and SGLTs was demonstrated in the membrane of MCs, and SGLT2 may function as a normal physiological glucose sensor and regulate cellular contractility because of its high sensitivity to short-term high glucose exposure (Kuriyama et al. 1992; Maki et al. 2019b; Wakisaka and Nagao 2017; Wakisaka et al. 2016). Exposure of MCs to high glucose significantly increased SGLT2 expression that was attenuated by Canagliflozin or ipragliflozin. Treatment with canagliflozin and phlorizin inhibited high-glucose-induced activation of PKC$\mathrm{NAD}(\mathrm{P}) \mathrm{H}$ oxidase pathway and PKC- TGF- $\beta$ pathway to increase ROS and Type IV collagen production (Donnelly et al. 1996; Maki et al. 2019b). SGLT2 in MCs has a direct protective effect on podocytes and MCs (Maki et al. 2019b). Notably, a low dose of canagliflozin improved albuminuria and mesangial expansion in type $2 d b / d b$ mice without lowering the blood glucose level (Maki et al. 2019b). Furthermore, the mesangial expansion in T1D Akita mice was significantly improved by canagliflozin than by insulin (Miyata et al. 2020).

\section{The Na/K-ATPase Signaling Prevented Hyperglycemia-Induced Apoptosis}

In primary cultures, a moderate increase in glucose concentration (10-15 mM, compared with normal physiological $5 \mathrm{mM}$ ) causes an SGLT-dependent apoptotic response in SGLT-expressing RPTs and MCs that was abolished by administration of SGLT inhibitor or knockdown of SGLT2 in RPTs, but not in podocytes that lack SGLTs (Nilsson et al. 2019). Most interestingly, treatment with a low concentration of a specific ligand/inhibitor of the Na/K-ATPase, ouabain (at $5 \mathrm{nM}$ ), prevented not only high glucose-induced apoptosis and changes in expression of Bax and Bcl-xL in RPTs and MCs, but also prevented high glucose-induced mitochondrial depolarization and increased ROS formation in RPTs (Nilsson et al. 2019). Ouabain (5 nM), which does not affect intracellular $\mathrm{Na}^{+}$concentration, triggers a calcium-NF- $\mathrm{KB}$ signal that protects kidney development from the adverse effects of malnutrition ( $\mathrm{Li}$ et al. 2010). Furthermore, exposure of rat RPTs to high glucose increased $\mathrm{Na} / \mathrm{K}$-ATPase activity and $\mathrm{Na} / \mathrm{K}-\mathrm{ATPase}-$ dependent energy 
consumption (Körner et al. 1994). These observations further emphasize the importance of the $\mathrm{Na} / \mathrm{K}$-ATPase and its signaling function. While ouabain $(5 \mathrm{nM})$ rescued RPTs from apoptosis in animal models of proteinuric disease (Burlaka et al. 2016) and hemolytic uremic syndrome (Burlaka et al. 2013), ouabain also rescued both RPTs and MCs from high glucose-triggered apoptosis (Nilsson et al. 2019). The underlying mechanism of a low dose of ouabain is the rebalance of the apoptotic factor Bax and antiapoptotic factor Bcl$\mathrm{xL}$, mainly through ouabain-stimulated Na/K-ATPase/IP3R/ $\mathrm{NF}-\kappa \mathrm{B}$ pathway. It will be of great interest to investigate the specific response of different types of cells from different organs since SGLT inhibitors execute various effects under different conditions.

\section{The Na/K-ATPase Signaling Stimulated Natriuresis}

From the proposed theories, the $\mathrm{Na} / \mathrm{K}$-ATPase ion transporter and signaling function of the Na/K-ATPase may present some similar effects of SGLT2 inhibitors. Under normal condition, the proximal tubular $\mathrm{Na} / \mathrm{K}$-ATPase is the driving force to reabsorb $65 \%$ of filtered $\mathrm{Na}^{+}$(Boron and Boulpaep 2012; Curthoys and Moe, 2014) ( 5\% by SGLT2), 100\% of filtered glucose ( $\sim 90 \%$ by SGLT2 and $\sim 10 \%$ by SGLT1). NHE3 is believed to be the rate-limiting step of total RPT $\mathrm{Na}^{+}$reabsorption as well as a critical regulator of acid-base equilibrium through the link between NHE3-mediated $\mathrm{H}^{+}$ secretion to $\mathrm{HCO}_{3}{ }^{-}$reabsorption by $\mathrm{Na}^{+} / \mathrm{HCO}_{3}{ }^{-}$co-transporter (Alpern 1990; Amemiya et al. 1995; Aronson 1983; Biemesderfer et al. 1993; Hamm et al. 2015). Activation of the Na/K-ATPase signaling function induces coordinated endocytosis of the Na/K-ATPase and NHE3 that leads to reduced $\mathrm{Na}^{+}$reabsorption and natriuresis to cause volume contraction and blood pressure-lowering (Cai et al. 2008; Liu et al. 2004, 2005, 2011; Liu and Shapiro 2007; Periyasamy et al. 2005). This reduced $\mathrm{Na}^{+}$reabsorption also reduced glomerular hyperfiltration, mimicking SGLT2 inhibitor-induced reduction of glomerular hyperfiltration by inhibiting $\mathrm{Na}^{+}$reabsorption in RPTs (Cherney et al. 2014b; Heerspink et al. 2016; Wanner et al. 2018). These reflect SGLT2 inhibitor's effects on NHE3, $\mathrm{Na}^{+}$homeostasis, and glomerular hyperfiltration. However, it is not clear whether and how the $\mathrm{Na} / \mathrm{K}$-ATPase signaling function affects glucose uptake through SGLTs. On the other hand, SGLT2 inhibitors reduce SGLT2-mediated $\mathrm{Na}^{+}$uptake into RPTs, which favors an E2(P) conformation of the Na/K-ATPase that tends to activate the signaling function. It worth noting that ouabain-induced trafficking of the $\mathrm{Na} / \mathrm{K}$-ATPase and NHE3 is independent of intracellular $\mathrm{Na}^{+}$change (Cai et al. 2008), but ouabain binding induces the $\mathrm{E} 2(\mathrm{P})$ conformation to inhibit Na/K-ATPase activity. A culprit is that the $\mathrm{Na} / \mathrm{K}$ ATPase signaling may increase ROS generation, whereas the SGLT2 inhibitor reduces oxidative stress. Since the $\mathrm{Na} / \mathrm{K}$-ATPase signaling is redox-sensitive (Liu et al. 2020), overstimulated signaling may chronically desensitize the signaling function and reduce $\mathrm{Na} / \mathrm{K}$-ATPase ion-transport capability by stimulating Na/K-ATPase/c-Src endocytosis. In clinical trials with antioxidant supplements, on the other side, the beneficial effect is controversial and not seen in most of the trials (Huang et al. 2006; Munzel et al. 2010; Touyz 2004). No matter what it may be, it seems like the balance of the redox status within a physiological range may be critical to maintaining beneficial ROS signaling. This disagreement worth futural investigation.

\section{The $\mathrm{Na} / \mathrm{K}$-ATPase Signaling Stimulated Oxidative Stress}

Other than reduced SGLT2-mediated $\mathrm{Na}^{+}$uptake, both ouabain and glucose oxidase cause direct protein carbonylation of $\mathrm{Pro}^{222}$ and $\mathrm{Thr}^{224}$ residues of the Na/K-ATPase $\alpha 1$ subunit in porcine proximal tubule LLC-PK1 cells (Yan et al. 2013). The Pro ${ }^{222}$ and $\mathrm{Thr}^{224}$ are located in peptide ${ }^{211}$ VDNSSLTGESEPQTR $^{225}$ [UniProtKB/Swiss-Prot No P05024 (AT1A1_ $P I G)$ ], which is $100 \%$ identical amongst human, pig, rat, and mouse. The $\mathrm{Pro}^{222}$ andThr ${ }^{224}$ are located in the actuator (A) domain, highly exposed and facing the nucleotide-binding (N) domain. Upon ouabain binding, Na/K-ATPase undergoes $\mathrm{E} 1(\mathrm{P})$ to $\mathrm{E} 2(\mathrm{P})$ conformational change, which affects the binding of the $\alpha 1$ subunit to signaling molecules such as c-Src and PI3K (Yatime et al. 2011). Protein carbonylation is reversible (decarbonylation) that may function as a regulatory mechanism of cell signaling (Wong et al. 2008, 2010). An undefined decarbonylation process of the $\mathrm{Na} / \mathrm{K}$ ATPase was also observed (Yan et al. 2013) as seen in the reversed $\mathrm{Na} / \mathrm{K}$-ATPase ion-pumping activity after removing ouabain from culture medium (Liu et al. 2004). It is possible that carbonylation modification might stabilize the $\mathrm{Na} / \mathrm{K}$ ATPase in a certain conformational status favoring ouabain binding to the $\mathrm{Na} / \mathrm{K}$-ATPase $\boldsymbol{\alpha} 1$ subunit and thus ouabain$\mathrm{Na} / \mathrm{K}$-ATPase signaling.

A feed-forward, redox-sensitive $\mathrm{Na} / \mathrm{K}$-ATPase signalingmediated oxidant amplification loop, stimulated either by CTS or ROS (Pratt et al. 2018). The Na/K-ATPase signaling and its amplification loop play an essential role in the regulation of cardiac hypertrophy, salt-sensitive hypertension in both Dahl salt-sensitive rats and polygenic obese TALLYHO/JngJ mice (a mouse model mimics the state of obesity in humans with a polygenic background of type 2 diabetes), RPT $\mathrm{Na}^{+}$reabsorption, systemic redox status, experimental CKD-induced cardiomyopathy (including left ventricle hypertrophy and cardiac/renal fibrosis) and anemia (Liu et al. 2020, 2016a, 2011,2016b; Pratt et al. 2018; Sodhi et al. 2020; Wang and Shapiro 2019; Yan et al. 2019). However, it worth noting that this positive feedback mechanism 
might chronically desensitize the signaling function and reduce $\mathrm{Na} / \mathrm{K}$-ATPase ion-transport capability by stimulating $\mathrm{Na} / \mathrm{K}-\mathrm{ATPase} / \mathrm{c}-\mathrm{Src}$ endocytosis (Cai et al. 2008; Liu et al. 2004, 2005). Compared with Dahl salt-resistant rats, Dahl salt-sensitive rats have a higher oxidative background in RPTs, and a high salt diet was unable to stimulate the $\mathrm{Na} / \mathrm{K}-\mathrm{ATPa} e$ signaling, natriuresis, and endocytosis of the $\mathrm{Na} / \mathrm{K}-\mathrm{ATPa} e$ and NHE3 (Liu et al. 2011).

CKD patients tend to have increased circulating CTS (Kolmakova et al. 2011; Komiyama et al. 2005). In addition, in experimental animal models of 5/6th partial nephrectomy (PNx) and marinobufagenin (MBG, one of the cardiotonic steroids) infusion, similar uremic cardiomyopathy phenotypes, such as elevated circulating MBG in PNx, cardiac hypertrophy, impaired cardiac function, and cardiac fibrosis, were observed (Elkareh et al. 2007; Kennedy et al. 2003, 2006; Zhang et al. 2019b).

The Na/K-ATPase/Src/ROS feed-forward oxidant amplification loop was also demonstrated in vivo in the development of uremic cardiomyopathy and anemia in a pole ligation PNx mouse model (AuWang et al. 2017; Liu et al. 2016a), which showed renal dysfunction with cardiac hypertrophy, cardiac fibrosis, and increase protein carbonylation. Administration of pNaKtide, an antagonist of $\mathrm{Na} / \mathrm{K}$-ATPase/ Src signaling that binds to c-Src kinase domain ( $\mathrm{Li}$ et al. 2009, 2011; Li and Xie 2009), attenuated the induced uremic cardiomyopathy. It indicates that the oxidant amplification loop is critical for the development of uremic cardiomyopathy.

\section{Oxidative Stress and Inflammation}

Oxidative stress is a well-recognized contributor in the development and progressions of diabetes/diabetic nephropathy, as well as in initiation and deterioration of cardiac structural changes and HF diabetic complications (Asmat et al. 2016; Bonventre 2012; Fine and Norman 2008; van der Pol et al. 2019). The Na/K-ATPase creates and maintains the $\mathrm{Na}^{+}$gradient across the membrane, accounts for most of the kidney's oxygen consumption for reabsorption of filtered $\mathrm{Na}^{+}$in RPTs (Hansell et al. 2013). The increase in cortical tubular $\mathrm{Na} / \mathrm{K}$-ATPase-related oxygen consumption in diabetic rats can be abolished by administering phlorizin, a non-selective inhibitor of SGLT 1 and 2 (Körner et al. 1994).

Oxidative stress and inflammation are essential contributors to heart failure and renal failure, and diabetic cardiac remodeling is redox-sensitive (Nikolic et al. 2021; Pickering et al. 2018; Wilson et al. 2018). A low dose of SGLT2 inhibitor canagliflozin has a renal-protective effect independent of its glucose-lowering effect but may involve inhibition of high-glucose-induced DAG-PKC activation and ROS overproduction (Maki et al. 2019a).
Upregulation of pro-inflammatory cytokines contributes to ROS generation and cardiac/renal fibrosis in DM and HF settings. In different animal models with T2DM, prediabetic metabolic syndrome, and induced diabetic cardiomyopathy, Dapagliflozin and Empagliflozin ameliorate cardiac fibrosis/ remodeling and cardiac function by its anti-inflammatory, anti-ROS, and anti-fibrotic effects (Arow et al. 2020; Kusaka et al. 2016; Lin et al. 2014; Ye et al. 2017). NADPH oxidases family is one of the major mediators of ROS production. In a rabbit model of $\mathrm{HF}$, antioxidant $\mathrm{N}$-acetylcysteine reduces NF- $\mathrm{\kappa B}$ activity and cardiomyocyte apoptosis (Wu et al. 2014). SGLT2 inhibitor Empagliffozin has been shown to inhibit NOX4 expression and activity, attenuate myocardial and renal oxidative stress/inflammation and fibrosis, decrease renal gene expression of inflammation and oxidative stress in diabetic mice and a transgenic rat model of prediabetic metabolic syndrome(Kusaka et al. 2016; Li et al. 2019; Terami et al. 2014).

SGLT2 inhibitors also improve the inflammatory and oxidative stress status in RPTs (Hatanaka et al. 2016; Panchapakesan et al. 2013; Shirakawa and Sano 2020). SGLT2 inhibitors reduce nuclear factor kappa B (NF-кB), interleukin-6 (IL-6), monocyte chemoattractant protein-1 (MCP-1), and other inflammatory factors implicated in DKD pathogenesis in experimental models of diabetes and in T2DM patients (Dekkers et al. 2018; Mancini et al. 2018). Under equal glycemic control with canagliflozin and glimepiride, only canagliflozin reduced pro-inflammatory mediators, suggesting a direct anti-inflammatory effect (Heerspink et al. 2019).

The Na/K-ATPase/Src/ROS feed-forward oxidant amplification loop has also been demonstrated to increase oxidative stress and pro-inflammatory cytokines in other types of animal models, including Western diet, obesity, aging, steatohepatitis, atherosclerosis, and adipogenesis (Pratt et al. 2019; Sodhi et al. 2017, 2018), which could be attenuated by administration of pNaKtide.

\section{$\mathrm{Ca}^{2+}$ and $\mathrm{Na}^{+}$Handling}

Heart failure is associated with impaired $\mathrm{Ca}^{2+}$ and $\mathrm{Na}^{+}$handling in failing cardiac myocytes that involves NHE1 and $\mathrm{Na}^{+} / \mathrm{Ca}^{2+}$ exchanger (NCX) that are linked to the $\mathrm{Na} / \mathrm{K}$ ATPase (Armoundas et al. 2003; Baartscheer et al. 2003a, b, 2005; Bers and Despa 2006; Müller-Ehmsen et al. 2003; Swift et al. 2008). Cardiac SGLT1 expression is upregulated to increase $\mathrm{Na}+$ influx and glucose uptake both in animal models of type 2 diabetes and in cardiac tissue harvested from patients with diabetic cardiomyopathy, and its activity contributes to the increase in intracellular $\mathrm{Na}^{+}$(Banerjee et al. 2009; Lambert et al. 2015). An increase in intracellular $\mathrm{Na}^{+}$has been shown to increase ROS generation and related hypertrophy and fibrosis (Kohlhaas et al. 2010; Murdoch et al. 2006; Seddon et al. 2007). In isolated ventricular 
myocytes from rabbits and rats, Empagliflozin reduced intracellular $\mathrm{Na}^{+}$and $\mathrm{Ca}^{2+}$ by directly inhibiting NHE, which is independent of SGLT2 activity (Baartscheer et al. 2017).

SGLT2 inhibitors shift metabolism from carbohydrates towards lipolysis, thus promoting mild ketogenesis, which may provide an alternative energy substrate to myocardial cells in the setting of ischemic stress (Ferrannini et al. 2016). SGLT2 inhibitors block NHE1, which is upregulated in heart failure. Long-term suppression of NHE1 in animals has been demonstrated to reduce oxidative stress and thus, myocardial fibrosis and left ventricular remodeling (Prasad et al. 2013). Empagliflozin was reported to block NHE1-induced cell death, hypertrophy, and tissue damage in heart (Sakata et al. 2000). In addition, although SGLT2 is not expressed in heart tissue, SGLT1 is present in lower levels in the myocardium (Kashiwagi et al. 2015). Some SGLT2 inhibitors could block both SGLT2 and SGLT1 in ex-vivo experiments (Lim et al. 2019), suggesting that SGLT2 inhibitors may benefit from the inhibition of SGLT1 in cardiac tissue.

NHE1 is the main NHE isoform expressed in myocardial tissue in the heart, regulating $\mathrm{pH}$ and volume in cardiomyocytes (Wakabayashi et al. 2013). The NHE1 activity is upregulated in the settings of HF and T2DM (Packer 2017) that is contributed to intracellular $\mathrm{Na}^{+}$and $\mathrm{Ca}^{2+}$ overload through coupling with the Na/K-ATPase, and NHE1 inhibition decreases cardiac remodeling, necrosis, and hypertrophy. All three SGLT2 inhibitors directly suppress the NHE1 activity in isolated cardiomyocytes (from mouse, rat, and rabbit) (Baartscheer et al. 2017; Uthman et al. 2018a), probably through direct binding to the $\mathrm{Na}^{+}$-binding site of NHE1 since SGLT2 is not found in heart up to now. In isolated cardiomyocytes from diabetic cardiomyopathy and diabetic animal models, Dapagliflozin and Empagliflozin reduce expression of NHE1 and NCX, and improve $\mathrm{Ca}^{2+}$ handling (Arow et al. 2020; Hammoudi et al. 2017; Joubert et al. 2017). Moreover, Empagliflozin maintains cell viability and ATP content following hypoxia/reoxygenation in cardiomyocytes and endothelial cells (Uthman et al. 2018b).

In cardiac-specific human NADPH oxidase 4 (Nox4) transgenic mice, an increase in NOX4 protein expression leads to an increase in ROS generation with cardiac interstitial fibrosis through activation of protein kinase B-mechanistic target of rapamycin (Akt-mTOR) and NF- $\mathrm{kB}$ signaling pathways (Zhao et al. 2015). The attenuation of cardiac oxidative stress and inflammation leads to weight loss, reduced subcutaneous fat mass, and visceral adipocyte size (Kusaka et al. 2016). Since there is no evidence of SGLT2 expression in the heart and SGLT1 is widely expressed in the myocardium, it further supports the idea that the cardio-protective effects of SGLT2 inhibitors might be stemmed from their renal-protective effects.

In the coupling of the function of SGLT1 and SGLT2, two other proteins, the $\mathrm{Na} / \mathrm{K}$-ATPase and glucose transporter, are important to remove the increased $\mathrm{Na}^{+}$and glucose to maintain the homeostasis. However, the functional interaction between $\mathrm{Na} / \mathrm{K}$-ATPase and SGLT proteins in renal and CV diseases has not been extensively studied. The $\mathrm{Na} / \mathrm{K}$-ATPase has been known to play an essential role in both renal and $\mathrm{CV}$ diseases. Human hearts express three alpha isoforms $(\alpha 1, \alpha 2, \alpha 3)$ of Na/K-ATPase (Gilmore-Hebert et al. 1989; Lucchesi and Sweadner 1991; Shamraj et al. 1991). Na/KATPase has been extensively studied for its ion transporting function since it was discovered in the 1950s. It was until the early 2000s, the signaling function of Na/K-ATPase started to be appreciated (Aizman and Aperia 2003; Shapiro and Tian 2011; Xie and Cai 2003; Zhang et al. 2019a).

Recent studies demonstrated that overstimulation of $\mathrm{Na} / \mathrm{K}$-ATPase signaling by increased endogenous CTS causes elevation of oxidative stress, which may play an important role in the uremic cardiomyopathy, including cardiac hypertrophy and cardiac fibrosis (Liu et al. 2020; Sodhi et al. 2020; Wang et al. 2020). In addition, low doses of CTS induced hypertension in rats and caused significant $\mathrm{CV}$ remodeling independent of their effect on blood pressure (Ferrandi et al. 2004; Jiang et al. 2007; Kennedy et al. 2006; Skoumal et al. 2007). Dilated cardiomyopathy patients tend to have decreased cardiac Na/K-ATPase expression (Norgaard et al. 1988; Schwinger et al. 2003). In isolated rat (neonatal and adult) cardiac myocytes, both ouabain and exogenously added glucose oxidase (or a bolus of $\mathrm{H}_{2} \mathrm{O}_{2}$ ) activate $\mathrm{Na} / \mathrm{K}$-ATPase signaling that leads to hypertrophy of cardiac myocytes (Liu et al. 2000, 2006; Tian et al. 2003; Xie et al. 1999). The Na/K-ATPase signaling is independent of intracellular $\mathrm{Ca}^{2+}$ and $\mathrm{Na}^{+}$concentrations (Liu et al. 2000; Xie et al. 1999).

From clinical data and animal studies, it has been demonstrated that decrease of $\mathrm{Na} / \mathrm{K}$-ATPase is an important risk factor for cardiac decompensation and dysfunction (Drummond et al. 2016, 2014; Ishino et al. 1999; Liu et al. 2012; Moseley et al. 2004; Norgaard et al. 1988; Schmidt et al. 1993; Semb et al. 1998). It has been reported that $\mathrm{Na} / \mathrm{K}$-ATPase concentration and activity were reduced in patients with heart failure, and cardiac ejection fraction was correlated with the amount of Na/K-ATPase protein level in heart tissue (Ishino et al. 1999; Moseley et al. 2004; Norgaard et al. 1988; Schmidt et al. 1993). Using the weighted gene co-expression network analysis (WGCNA) based on data from a large cohort of heart transplant patients and their donors (GEO141910), we identified the gene that includes $\mathrm{Na} / \mathrm{K}$-ATPase was significantly associated with the phenotype of dilated cardiomyopathy. More importantly, the Na/K-ATPase expression level in this cohort strongly correlates with the left ventricle ejection fraction (LVEF), consistent with the previous findings in heart transplant patients (Ishino et al. 
1999; Norgaard et al. 1988; Schmidt et al. 1993). More recently, it was demonstrated that reduction of $\alpha 1$ isoform of $\mathrm{Na} / \mathrm{K}-\mathrm{ATPase}$ causes tissue fibrosis and cardiac cell apoptosis in response to Na/K-ATPase ligand treatment and in the animal model of CKD (Drummond et al. 2014; Liu et al. 2012). It was also found that CKD induces activation of $\mathrm{Na} / \mathrm{K}$-ATPase-mediated $\mathrm{Src}$ and its downstream target $\mathrm{NF \kappa B}$, which results in a reduction of miR-29b-3p expression and cardiac tissue fibrosis (Drummond et al. 2016, 2018). Disrupting the Na/K-ATPase-related signaling and inhibition of Src activation by pNaKtide increased miR-29b-3p expression in heart tissue and thus attenuated cardiac fibrosis in these animals (Drummond et al. 2018). In LLC-PK1 cells, high-glucose treatment at the basolateral side alone or basolateral plus apical sides, but not in the apical side alone, upregulates SGLT2 expression and activity via activation of the GLUT2/importin- $\alpha 1 /$ HNF-1 $\alpha$ pathway (Umino et al. 2018). Interestingly, in cultured human proximal tubule cells, $\mathrm{H}_{2} \mathrm{O}_{2}$ but not highglucose causes upregulation of SGLT2 protein expression and activity via ROS generation (Nakamura et al. 2015). SGLT2 deficiency causes glucosuria without volume depletion (Vallon et al. 2011). Proximal tubule-specific NHE3 knockout upregulates SGLT2 expression and lowers blood pressure by increasing the pressure natriuresis (Li et al. 2018). Model-based clinical data analysis indicates that NHE3 inhibition is a required mechanism for the gliflozin-induced natriuretic effect (Hallow et al. 2018). Exposure of rat proximal tubules to high glucose results in increased $\mathrm{Na}$ /K-ATPase activity and $\mathrm{Na} / \mathrm{K}$-ATPasedependent energy consumption (Körner et al. 1994). Diabetic rats also showed significantly higher GFR, renal oxygen metabolism, and $\mathrm{Na}^{+}$reabsorption than the control rats, as well as higher $\mathrm{Na} / \mathrm{K}$-ATPase activity in cortical tubular but not glomerular tissue. These changes were blocked by Phlorizin treatment(Körner et al. 1994). Diabetes is associated with increased renal oxygen metabolism secondary to the increase in coupled $\mathrm{Na}^{+}$reabsorption via the SGLTs and Na/K-ATPase, which might contribute to the hyperperfusion and hyperfiltration in the diabetic kidney. Damage of tubular cells causes interstitial fibrosis and glomerular tubular dissociation that can be abolished by catalase overexpression (Brezniceanu et al. 2008). Apoptosis is associated with increased secretion of transforming growth factor- $\beta$ (TGF- $\beta$ ) and other proinflammatory cytokines that drive the fibrotic process (Meng et al. 2016; Ramesh et al. 2009), it was proposed that apoptotic responses of RPTs to hyperglycemia are a major cause of the progressive interstitial fibrosis in DKD (Nilsson et al. 2019). On the other hand, activation of the Na/K-ATPaseSrc signaling pathways also increased ROS generation and fibrosis in kidney and heart in $5 / 6^{\text {th }} \mathrm{PNx}$ mouse/rat model

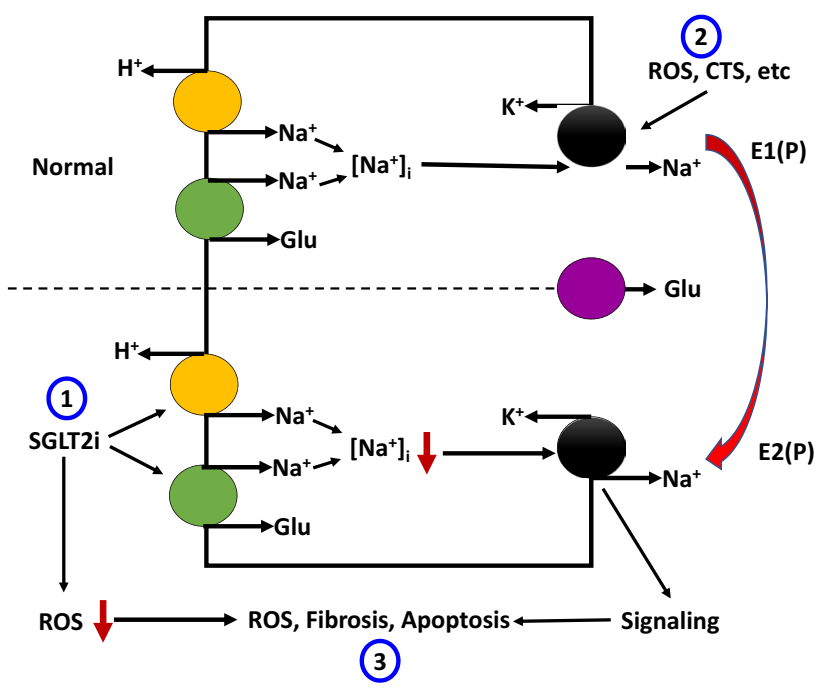

Fig. 1 Schematic illustration of possible interactions between SGLT2 and $\mathrm{Na} / \mathrm{K}$-ATPase. (1) SGLT2 inhibitors inhibit apical $\mathrm{Na}^{+}$entry through both SGLT2 and NHE3 that may account for up to $70 \%$ of $\mathrm{Na}^{+}$entry in RPTs, leading to lower intracellular $\mathrm{Na}^{+}$concentration, and thus the $\mathrm{Na} / \mathrm{K}-\mathrm{ATPa} e$ activity. This situation favors the $\mathrm{Na} / \mathrm{K}$ ATPase in an E2(P) status that favors activation of the Na/K-ATPase signaling. (2) On the other side, increases in CTS or ROS cause inhibition of the $\mathrm{Na} / \mathrm{K}$-ATPase activity that increases intracellular $\mathrm{Na}^{+}$ concentration, leading to inhibition of SGLT2 and NHE3. CTS or ROS also stimulates $\mathrm{Na} / \mathrm{K}-\mathrm{ATP}$ ase signaling and subsequent endocytosis of the Na/K-ATPase and NHE3 and fibrotic response. (3) While activation of the $\mathrm{Na} / \mathrm{K}$-ATPase signaling increases oxidative stress and fibrosis, SGLT2 inhibitors reduce oxidative stress to counterbalance the fibrotic response. It is worth noting that a low dose of ouabain prevents hyperglycemia-induced apoptosis and ROS generation

and Dahl salt-sensitive hypertensive rat model (Haller et al. 2012; Liu et al. 2016a; Zhang et al. 2019b), which might be contributed to the activation of TGF- $\beta$, mammalian target of rapamycin (mTOR), and PLC/PKC- $\delta$ pathway, which induced phosphorylation and degradation of transcription factor Friend leukemia integration-1 (Fli-1, a negative regulator of collagen synthesis) (Elkareh et al. 2007, 2009; Haller et al. 2016; Zhang et al. 2019b). In these models, fibrotic responses to PNx surgery and high salt diet challenge were significantly attenuated by administration of pNaKtide (a specific peptide to block Na/KATPase-Src signaling) or monoclonal antibody against MBG (Fig. 1).

\section{Conclusion}

Other than the glucose-lowering property as initially designed, SGLT2 inhibitors show profound "off-target" but beneficial cardiorenal-protective effects, promoting mechanism investigations and theories. The $\mathrm{Na} / \mathrm{K}$-ATPase is the driving force for the reabsorption of $\mathrm{Na}^{+}$and glucose as the 
primary ion transporter, also affects other cellular processes as a signal transducer. Compared with SGLT2 inhibitor's beneficial effects, the $\mathrm{Na} / \mathrm{K}$-ATPase and its signaling function exert some similar effects mainly through the kidney, such as natriuresis, blood pressure-lowering, and through the heart, such as reduction of cardiac hypertrophy and fibrosis. Even though the $\mathrm{Na} / \mathrm{K}$-ATPase signaling-mediated oxidant amplification loop was established in RPTs, the similarity of the $\mathrm{Na} / \mathrm{K}$-ATPase signaling cascades in both cardiac myocytes and renal proximal tubule cells suggests that this amplification loop might be shared in both cell types. For example, Ouabain-induced endocytosis of the Na/K-ATPase was first observed in HeLa cells, chick embryo heart cells, and Girardi heart cells (Aiton et al. 1981; Algharably et al. 1986; Cook 1982; Lamb and McCall 1971; Lamb and Ogden 1982). Since the signaling function of the $\mathrm{Na} / \mathrm{K}$-ATPase is redox-sensitive, a balanced ROS environment would be more beneficial. The possibility that the Na/K-ATPase and its signaling affect SGLT2 function, and vice versa, worth exploring.

Open Access This article is licensed under a Creative Commons Attribution 4.0 International License, which permits use, sharing, adaptation, distribution and reproduction in any medium or format, as long as you give appropriate credit to the original author(s) and the source, provide a link to the Creative Commons licence, and indicate if changes were made. The images or other third party material in this article are included in the article's Creative Commons licence, unless indicated otherwise in a credit line to the material. If material is not included in the article's Creative Commons licence and your intended use is not permitted by statutory regulation or exceeds the permitted use, you will need to obtain permission directly from the copyright holder. To view a copy of this licence, visit http://creativecommons.org/licenses/by/4.0/.

\section{References}

Abrass CK (1995) Diabetic nephropathy. Mechanisms of mesangial matrix expansion. West J Med 162:318-321

Aiton JF, Lamb JF, Ogden P (1981) Down-regulation of the sodium pump following chronic exposure of HeLa cells and chick embryo heart cells to ouabain. Br J Pharmacol 73:333-340

Aizman O, Aperia A (2003) Na, K-ATPase as a signal transducer. Ann NY Acad Sci 986:489-496

Algharably N, Owler D, Lamb JF (1986) The rate of uptake of cardiac glycosides into human cultured cells and the effects of chloroquine on it. Biochem Pharmacol 35:3571-3581

Alpern RJ (1990) Cell mechanisms of proximal tubule acidification. Physiol Rev 70:79-114

Amemiya M, Loffing J, Lotscher M, Kaissling B, Alpern RJ, Moe OW (1995) Expression of NHE-3 in the apical membrane of rat renal proximal tubule and thick ascending limb. Kidney Int 48:1206-1215

Aperia A (2007) New roles for an old enzyme: Na, K-ATPase emerges as an interesting drug target. J Intern Med 261:44-52

Armoundas AA, Hobai IA, Tomaselli GF, Winslow RL, O'Rourke B (2003) Role of sodium-calcium exchanger in modulating the action potential of ventricular myocytes from normal and failing hearts. Circ Res 93:46-53

Aronson PS (1983) Mechanisms of active $\mathrm{H}+$ secretion in the proximal tubule. Am J Physiol Renal Physiol 245:F647-F659

Arow M, Waldman M, Yadin D, Nudelman V, Shainberg A, Abraham NG, Freimark D, Kornowski R, Aravot D, Hochhauser E, Arad M (2020) Sodium-glucose cotransporter 2 inhibitor Dapagliflozin attenuates diabetic cardiomyopathy. Cardiovasc Diabetol 19:7

Asmat U, Abad K, Ismail K (2016) Diabetes mellitus and oxidative stress-A concise review. Saudi Pharm J 24:547-553

Baartscheer A, Schumacher CA, Belterman CN, Coronel R, Fiolet JW (2003a) $[\mathrm{Na}+] \mathrm{i}$ and the driving force of the $\mathrm{Na}+/ \mathrm{Ca} 2+-$ exchanger in heart failure. Cardiovasc Res 57:986-995

Baartscheer A, Schumacher CA, van Borren MM, Belterman CN, Coronel R, Fiolet JW (2003b) Increased $\mathrm{Na}+/ \mathrm{H}+$-exchange activity is the cause of increased $\left[\mathrm{Na}^{+}\right]_{\mathrm{i}}$ and underlies disturbed calcium handling in the rabbit pressure and volume overload heart failure model. Cardiovasc Res 57:1015-1024

Baartscheer A, Schumacher CA, van Borren MM, Belterman CN, Coronel R, Opthof T, Fiolet JW (2005) Chronic inhibition of $\mathrm{Na}+\mathrm{H}+$-exchanger attenuates cardiac hypertrophy and prevents cellular remodeling in heart failure. Cardiovasc Res 65:83-92

Baartscheer A, Schumacher CA, Wüst RC, Fiolet JW, Stienen GJ, Coronel R, Zuurbier CJ (2017) Empagliflozin decreases myocardial cytoplasmic $\mathrm{Na}^{+}$through inhibition of the cardiac $\mathrm{Na}^{+} / \mathrm{H}^{+}$ exchanger in rats and rabbits. Diabetologia 60:568-573

Bagrov AY, Shapiro JI (2008) Endogenous digitalis: pathophysiologic roles and therapeutic applications. Nat Clin Pract Nephrol 4:378-392

Bagrov AY, Shapiro JI, Fedorova OV (2009) Endogenous cardiotonic steroids: physiology, pharmacology, and novel therapeutic targets. Pharmacol Rev 61:9-38

Baker WL, Smyth LR, Riche DM, Bourret EM, Chamberlin KW, White WB (2014) Effects of sodium-glucose co-transporter 2 inhibitors on blood pressure: a systematic review and metaanalysis. J Am Soc Hypertens 8:262-275

Banerjee SK, McGaffin KR, Pastor-Soler NM, Ahmad F (2009) SGLT1 is a novel cardiac glucose transporter that is perturbed in disease states. Cardiovasc Res 84:111-118

Bell RM, Yellon DM (2018) SGLT2 inhibitors: hypotheses on the mechanism of cardiovascular protection. Lancet Diabetes Endocrinol 6:435-437

Bell GI, Kayano T, Buse JB, Burant CF, Takeda J, Lin D, Fukumoto H, Seino S (1990) Molecular biology of mammalian glucose transporters. Diabetes Care 13:198-208

Bergman H, Drury DR (1938) The relationship of kidney function to the glucose utilization of the extra abdominal tissues. Am J Physiol Leg Content 124:279-284

Bers DM, Despa S (2006) Cardiac myocytes $\mathrm{Ca}^{2+}$ and $\mathrm{Na}^{+}$regulation in normal and failing hearts. J Pharmacol Sci 100:315-322

Bertero E, Prates Roma L, Ameri P, Maack C (2017) Cardiac effects of SGLT2 inhibitors: the sodium hypothesis. Cardiovasc Res 114:12-18

Bhatt DL, Szarek M, Pitt B, Cannon CP, Leiter LA, McGuire DK, Lewis JB, Riddle MC, Inzucchi SE, Kosiborod MN, Cherney DZI, Dwyer JP, Scirica BM, Bailey CJ, Díaz R, Ray KK, Udell JA, Lopes RD, Lapuerta P, Steg PG (2020) Sotagliflozin in patients with diabetes and chronic kidney disease. N Engl J Med 384:129-139

Biemesderfer D, Pizzonia J, Abu-Alfa A, Exner M, Reilly R, Igarashi P, Aronson PS (1993) NHE3: a Na ${ }^{+} / \mathrm{H}^{+}$exchanger isoform of renal brush border. Am J Physiol 265:F736-F742

Blanco G, Mercer RW (1998) Isozymes of the Na-K-ATPase: heterogeneity in structure, diversity in function. Am J Physiol 275:F633-F650 
Blaustein MP (1993) Physiological effects of endogenous ouabain: control of intracellular $\mathrm{Ca}^{2+}$ stores and cell responsiveness. Am J Physiol 264:C1367-C1387

Bonventre JV (2012) Can we target tubular damage to prevent renal function decline in diabetes? Semin Nephrol 32:452-462

Boron WF, Boulpaep EL (2012) Medical physiology : a cellular and molecular approach Saunders. Elsevier, Philadelphia, PA

Brezniceanu ML, Liu F, Wei CC, Chénier I, Godin N, Zhang SL, Filep JG, Ingelfinger JR, Chan JS (2008) Attenuation of interstitial fibrosis and tubular apoptosis in $\mathrm{db} / \mathrm{db}$ transgenic mice overexpressing catalase in renal proximal tubular cells. Diabetes 57:451-459

Bricker NS (1967) The control of sodium excretion with normal and reduced nephron populations. The pre-eminence of third factor. Am J Med 43:313-321

Brown GK (2000) Glucose transporters: structure, function and consequences of deficiency. J Inherit Metab Dis 23:237-246

Burlaka I, Liu XL, Rebetz J, Arvidsson I, Yang L, Brismar H, Karpman D, Aperia A (2013) Ouabain protects against Shiga toxintriggered apoptosis by reversing the imbalance between Bax and Bcl-xL. J Am Soc Nephrol 24:1413-1423

Burlaka I, Nilsson LM, Scott L, Holtbäck U, Eklöf AC, Fogo AB, Brismar H, Aperia A (2016) Prevention of apoptosis averts glomerular tubular disconnection and podocyte loss in proteinuric kidney disease. Kidney Int 90:135-148

Cai H, Wu L, Qu W, Malhotra D, Xie Z, Shapiro JI, Liu J (2008) Regulation of apical NHE3 trafficking by ouabain-induced activation of the basolateral $\mathrm{Na}^{+}-\mathrm{K}^{+}$-ATPase receptor complex. Am J Physiol Cell Physiol 294:C555-C563

Cherney DZ, Perkins BA, Soleymanlou N, Har R, Fagan N, Johansen OE, Woerle HJ, von Eynatten M, Broedl UC (2014a) The effect of empagliflozin on arterial stiffness and heart rate variability in subjects with uncomplicated type 1 diabetes mellitus. Cardiovasc Diabetol 13:28

Cherney DZ, Perkins BA, Soleymanlou N, Maione M, Lai V, Lee A, Fagan NM, Woerle HJ, Johansen OE, Broedl UC, von Eynatten M (2014b) Renal hemodynamic effect of sodium-glucose cotransporter 2 inhibition in patients with type 1 diabetes mellitus. Circulation 129:587-597

Cook JS, Tate EH, Shaffer C (1982) Uptake of [3H]ouabain from the cell surface into the lysosomal compartment of HeLa cells. J Cell Physiol 110:84-92

Curthoys NP, Moe OW (2014) Proximal Tubule function and response to acidosis. Clin J Am Soc Nephrol 9:1627-1638

Dahl LK, Knudsen KD, Iwai J (1969) Humoral transmission of hypertension: evidence from parabiosis. Circ Res 24(Suppl):21-33

de Wardener HE, MacGregor GA (1980) Dahl's hypothesis that a saluretic substance may be responsible for a sustained rise in arterial pressure: its possible role in essential hypertension. Kidney Int 18:1-9

Dekkers CCJ, Petrykiv S, Laverman GD, Cherney DZ, Gansevoort RT, Heerspink HJL (2018) Effects of the SGLT-2 inhibitor dapagliflozin on glomerular and tubular injury markers. Diabetes Obes Metab 20:1988-1993

Desouza CV, Gupta N, Patel A (2015) Cardiometabolic effects of a new class of antidiabetic agents. Clin Ther 37:1178-1194

Donnelly SM, Zhou XP, Huang JT, Whiteside CI (1996) Prevention of early glomerulopathy with tolrestat in the streptozotocin-induced diabetic rat. Biochem Cell Biol 74:355-362

Dostanic I, Paul RJ, Lorenz JN, Theriault S, Van Huysse JW, Lingrel JB (2005) The alpha2-isoform of Na-K-ATPase mediates ouabaininduced hypertension in mice and increased vascular contractility in vitro. Am J Physiol Heart Circ Physiol 288:H477-H485

Dostanic-Larson I, Van Huysse JW, Lorenz JN, Lingrel JB (2005) The highly conserved cardiac glycoside binding site of Na, K-ATPase plays a role in blood pressure regulation. Proc Natl Acad Sci USA 102:15845-15850

Drummond CA, Sayed M, Evans KL, Shi H, Wang X, Haller ST, Liu J, Cooper CJ, Xie Z, Shapiro JI, Tian J (2014) Reduction of $\mathrm{Na} / \mathrm{K}$-ATPase affects cardiac remodeling and increases c-kit cell abundance in partial nephrectomized mice. Am J Physiol Heart Circ Physiol 306:H1631-H1643

Drummond CA, Hill MC, Shi H, Fan X, Xie JX, Haller ST, Kennedy DJ, Liu J, Garrett MR, Xie Z, Cooper CJ, Shapiro JI, Tian J (2016) $\mathrm{Na} / \mathrm{K}$-ATPase signaling regulates collagen synthesis through microRNA-29b-3p in cardiac fibroblasts. Physiol Genom 48:220-229

Drummond CA, Fan X, Haller ST, Kennedy DJ, Liu J, Tian J (2018) $\mathrm{Na} / \mathrm{K}$-ATPase signaling mediates miR-29b-3p regulation and cardiac fibrosis formation in mice with chronic kidney disease. PLoS ONE 13:e0197688

Duckworth W, Abraira C, Moritz T, Reda D, Emanuele N, Reaven PD, Zieve FJ, Marks J, Davis SN, Hayward R, Warren SR, Goldman S, McCarren M, Vitek ME, Henderson WG, Huang GD, Investigators V (2009) Glucose control and vascular complications in veterans with type 2 diabetes. N Engl J Med 360:129-139

Elkareh J, Kennedy DJ, Yashaswi B, Vetteth S, Shidyak A, Kim EG, Smaili S, Periyasamy SM, Hariri IM, Fedorova L, Liu J, Wu L, Kahaleh MB, Xie Z, Malhotra D, Fedorova OV, Kashkin VA, Bagrov AY, Shapiro JI (2007) Marinobufagenin stimulates fibroblast collagen production and causes fibrosis in experimental uremic cardiomyopathy. Hypertension 49:215-224

Elkareh J, Periyasamy SM, Shidyak A, Vetteth S, Schroeder J, Raju V, Hariri IM, El-Okdi N, Gupta S, Fedorova L, Liu J, Fedorova OV, Kahaleh MB, Xie Z, Malhotra D, Watson DK, Bagrov AY, Shapiro JI (2009) Marinobufagenin induces increases in procollagen expression in a process involving protein kinase $\mathrm{C}$ and Fli-1: implications for uremic cardiomyopathy. Am J Physiol Ren Physiol 296:F1219-F1226

Fathi A, Vickneson K, Singh JS (2021) SGLT2-inhibitors; more than just glycosuria and diuresis. Heart Fail Rev 26:623-642

Fedorova OV, Doris PA, Bagrov AY (1998) Endogenous marinobufagenin-like factor in acute plasma volume expansion. Clin Exp Hypertens 20:581-591

Fedorova OV, Kolodkin NI, Agalakova NI, Lakatta EG, Bagrov AY (2001) Marinobufagenin, an endogenous alpha-1 sodium pump ligand, in hypertensive Dahl salt-sensitive rats. Hypertension 37:462-466

Fedorova OV, Talan MI, Agalakova NI, Lakatta EG, Bagrov AY (2002) Endogenous ligand of alpha(1) sodium pump, marinobufagenin, is a novel mediator of sodium chloride-dependent hypertension. Circulation 105:1122-1127

Fedorova OV, Agalakova NI, Talan MI, Lakatta EG, Bagrov AY (2005) Brain ouabain stimulates peripheral marinobufagenin via angiotensin II signalling in NaCl-loaded Dahl-S rats. J Hypertens 23:1515-1523

Ferrandi M, Molinari I, Barassi P, Minotti E, Bianchi G, Ferrari P (2004) Organ hypertrophic signaling within caveolae membrane subdomains triggered by ouabain and antagonized by PST 2238. J Biol Chem 279:33306-33314

Ferrannini E, Mark M, Mayoux E (2016) CV protection in the EMPA-REG OUTCOME Trial: A "Thrifty Substrate" Hypothesis. Diabetes Care 39:1108-1114

Ferrari P, Ferrandi M, Valentini G, Bianchi G (2006) Rostafuroxin: an ouabain antagonist that corrects renal and vascular $\mathrm{Na}^{+}-\mathrm{K}^{+}$- ATPase alterations in ouabain and adducin-dependent hypertension. Am J Physiol Regul Integr Comp Physiol 290:R529-R535

Filippatos TD, Liontos A, Papakitsou I, Elisaf MS (2019) SGLT2 inhibitors and cardioprotection: a matter of debate and multiple hypotheses. Postgrad Med 131:82-88 
Fine LG, Norman JT (2008) Chronic hypoxia as a mechanism of progression of chronic kidney diseases: from hypothesis to novel therapeutics. Kidney Int 74:867-872

Gerich JE (2010) Role of the kidney in normal glucose homeostasis and in the hyperglycaemia of diabetes mellitus: therapeutic implications. Diabet Med 27:136-142

Gilmore-Hebert M, Schneider JW, Greene AL, Berliner N, Stolle CA, Lomax K, Mercer RW, Benz EJ Jr (1989) Expression of multiple $\mathrm{Na}^{+}, \mathrm{K}^{+}$-adenosine triphosphatase isoform genes in human hematopoietic cells. Behavior of the novel A3 isoform during induced maturation of HL60 cells. J Clin Invest 84:347-351

Gnudi L, Thomas SM, Viberti G (2007) Mechanical forces in diabetic kidney disease: a trigger for impaired glucose metabolism. J Am Soc Nephrol 18:2226-2232

Gottlieb SS, Rogowski AC, Weinberg M, Krichten CM, Hamilton BP, Hamlyn JM (1992) Elevated concentrations of endogenous ouabain in patients with congestive heart failure. Circulation $86: 420-425$

Haddy FJ, Pamnani MB (1998) Role of ouabain-like factors and Na-KATPase inhibitors in hypertension-some old and recent findings. Clin Exp Hypertens 20:499-508

Haller ST, Kennedy DJ, Shidyak A, Budny GV, Malhotra D, Fedorova OV, Shapiro JI, Bagrov AY (2012) Monoclonal antibody against marinobufagenin reverses cardiac fibrosis in rats with chronic renal failure. Am J Hypertens 25:690-696

Haller ST, Yan Y, Drummond CA, Xie J, Tian J, Kennedy DJ, Shilova VY, Xie Z, Liu J, Cooper CJ, Malhotra D (2016) Rapamycin attenuates cardiac fibrosis in experimental uremic cardiomyopathy by reducing marinobufagenin levels and inhibiting downstream pro-fibrotic signaling. J Am Heart Assoc 5(10):e004106

Hallow KM, Greasley PJ, Helmlinger G, Chu L, Heerspink HJ, Boulton DW (2018) Evaluation of renal and cardiovascular protection mechanisms of SGLT2 inhibitors: model-based analysis of clinical data. Am J Physiol Ren Physiol 315:F1295-F1306

Hamlyn JM, Blaustein MP, Bova S, DuCharme DW, Harris DW, Mandel F, Mathews WR, Ludens JH (1991) Identification and characterization of a ouabain-like compound from human plasma. Proc Natl Acad Sci USA 88:6259-6263

Hamlyn JM, Lu ZR, Manunta P, Ludens JH, Kimura K, Shah JR, Laredo J, Hamilton JP, Hamilton MJ, Hamilton BP (1998) Observations on the nature, biosynthesis, secretion and significance of endogenous ouabain. Clin Exp Hypertens 20:523-533

Hamm LL, Nakhoul N, Hering-Smith KS (2015) Acid-Base Homeostasis. Clin J Am Soc Nephrol 10:2232-2242

Hammoudi N, Jeong D, Singh R, Farhat A, Komajda M, Mayoux E, Hajjar R, Lebeche D (2017) Empagliflozin improves left ventricular diastolic dysfunction in a genetic model of Type 2 diabetes. Cardiovasc Drugs Ther 31:233-246

Hansell P, Welch WJ, Blantz RC, Palm F (2013) Determinants of kidney oxygen consumption and their relationship to tissue oxygen tension in diabetes and hypertension. Clin Exp Pharmacol Physiol 40:123-137

Hasegawa T, Masugi F, Ogihara T, Kumahara Y (1987) Increase in plasma ouabainlike inhibitor of $\mathrm{Na}^{+}, \mathrm{K}^{+}$-ATPase with high sodium intake in patients with essential hypertension. J Clin Hypertens 3:419-429

Hatanaka T, Ogawa D, Tachibana H, Eguchi J, Inoue T, Yamada H, Takei K, Makino H, Wada J (2016) Inhibition of SGLT2 alleviates diabetic nephropathy by suppressing high glucose-induced oxidative stress in type 1 diabetic mice. Pharmacol Res Perspect 4:00239

Hediger MA, Rhoads DB (1994) Molecular physiology of sodiumglucose cotransporters. Physiol Rev 74:993-1026

Heerspink HJ, Perkins BA, Fitchett DH, Husain M, Cherney DZ (2016) Sodium glucose cotransporter 2 inhibitors in the treatment of diabetes mellitus: cardiovascular and kidney effects, potential mechanisms, and clinical applications. Circulation 134:752-772

Heerspink HJL, Perco P, Mulder S, Leierer J, Hansen MK, Heinzel A, Mayer G (2019) Canagliflozin reduces inflammation and fibrosis biomarkers: a potential mechanism of action for beneficial effects of SGLT2 inhibitors in diabetic kidney disease. Diabetologia 62:1154-1166

Heerspink HJL, Stefánsson BV, Correa-Rotter R, Chertow GM, Greene T, Hou F-F, Mann JFE, McMurray JJV, Lindberg M, Rossing P, Sjöström CD, Toto RD, Langkilde A-M, Wheeler DC (2020) Dapagliflozin in patients with chronic kidney disease. N Engl J Med 383:1436-1446

Helal I, Fick-Brosnahan GM, Reed-Gitomer B, Schrier RW (2012) Glomerular hyperfiltration: definitions, mechanisms and clinical implications. Nat Rev Nephrol 8:293-300

Heywood JT, Fonarow GC, Costanzo MR, Mathur VS, Wigneswaran JR, Wynne J (2007) High prevalence of renal dysfunction and its impact on outcome in 118,465 patients hospitalized with acute decompensated heart failure: a report from the ADHERE database. J Card Fail 13:422-430

Hillege HL, Nitsch D, Pfeffer MA, Swedberg K, McMurray JJ, Yusuf S, Granger CB, Michelson EL, Ostergren J, Cornel JH, de Zeeuw D, Pocock S, van Veldhuisen DJ (2006) Renal function as a predictor of outcome in a broad spectrum of patients with heart failure. Circulation 113:671-678

Huang H-Y, Caballero B, Chang S, Alberg AJ, Semba RD, Schneyer CR, Wilson RF, Cheng T-Y, Vassy J, Prokopowicz G, Barnes GJ, Bass EB (2006) The efficacy and safety of multivitamin and mineral supplement use to prevent cancer and chronic disease in adults: A systematic review for a National Institutes of Health State-of-the-Science Conference. Ann Intern Med 145:372-385

Hung SC, Kuo KL, Peng CH, Wu CH, Lien YC, Wang YC, Tarng DC (2014) Volume overload correlates with cardiovascular risk factors in patients with chronic kidney disease. Kidney Int 85:703-709

Inzucchi SE, Kosiborod M, Fitchett D, Wanner C, Hehnke U, Kaspers S, George JT, Zinman B (2018) Improvement in cardiovascular outcomes with empagliflozin is independent of glycemic control. Circulation 138:1904-1907

Ishino K, Botker HE, Clausen T, Hetzer R, Sehested J (1999) Myocardial adenine nucleotides, glycogen, and $\mathrm{Na}$, K-ATPase in patients with idiopathic dilated cardiomyopathy requiring mechanical circulatory support. Am J Cardiol 83:396-399

Jhund PS, Solomon SD, Docherty KF, Heerspink HJL, Anand IS, Böhm M, Chopra V, Boer RAd, Desai AS, Ge J, Kitakaze M, Merkley B, O'Meara E, Shou M, Tereshchenko S, Verma S, Vinh PN, Inzucchi SE, Køber L, Kosiborod MN, Martinez FA, Ponikowski P, Sabatine MS, Bengtsson O, Langkilde AM, Sjöstrand M, McMurray JJV (2021) Efficacy of dapagliflozin on renal function and outcomes in patients with heart failure with reduced ejection fraction. Circulation 143:298-309

Jiang X, Ren YP, Lv ZR (2007) Ouabain induces cardiac remodeling in rats independent of blood pressure. Acta Pharmacol Sin 28:344-352

Joubert M, Jagu B, Montaigne D, Marechal X, Tesse A, Ayer A, Dollet L, Le May C, Toumaniantz G, Manrique A, Charpentier F, Staels B, Magré J, Cariou B, Prieur X (2017) The sodiumglucose cotransporter 2 inhibitor dapagliflozin prevents cardiomyopathy in a diabetic lipodystrophic mouse model. Diabetes 66:1030-1040

Kaplan JH (2002) Biochemistry of Na, K-ATPase. Annu Rev Biochem 71:511-535

Kario K, Okada K, Kato M, Nishizawa M, Yoshida T, Asano T, Uchiyama K, Niijima Y, Katsuya T, Urata H, Osuga JI, Fujiwara T, Yamazaki S, Tomitani N, Kanegae H (2018) 24-hour blood pressure-lowering effect of an sglt-2 inhibitor in patients 
with diabetes and uncontrolled nocturnal hypertension: results from the randomized, placebo-controlled SACRA study. Circulation 139:2089

Kashiwagi Y, Nagoshi T, Yoshino T, Tanaka TD, Ito K, Harada T, Takahashi H, Ikegami M, Anzawa R, Yoshimura M (2015) Expression of SGLT1 in human hearts and impairment of cardiac glucose uptake by phlorizin during ischemia-reperfusion injury in mice. PLoS ONE 10:e0130605

Kaunitz JD (2006) Membrane transport proteins: not just for transport anymore. Am J Physiol Renal Physiol 290:F995-F996

Kennedy D, Omran E, Periyasamy SM, Nadoor J, Priyadarshi A, Willey JC, Malhotra D, Xie Z, Shapiro JI (2003) Effect of chronic renal failure on cardiac contractile function, calcium cycling, and gene expression of proteins important for calcium homeostasis in the rat. J Am Soc Nephrol 14:90-97

Kennedy DJ, Vetteth S, Periyasamy SM, Kanj M, Fedorova L, Khouri S, Kahaleh MB, Xie Z, Malhotra D, Kolodkin NI, Lakatta EG, Fedorova OV, Bagrov AY, Shapiro JI (2006) Central role for the cardiotonic steroid marinobufagenin in the pathogenesis of experimental uremic cardiomyopathy. Hypertension 47:488-495

Kidokoro K, Cherney DZI, Bozovic A, Nagasu H, Satoh M, Kanda E, Sasaki T, Kashihara N (2019) Evaluation of glomerular hemodynamic function by empagliflozin in diabetic mice using in vivo imaging. Circulation 140:303-315

Kohlhaas M, Liu T, Knopp A, Zeller T, Ong MF, Böhm M, O’Rourke B, Maack C (2010) Elevated cytosolic $\mathrm{Na}^{+}$increases mitochondrial formation of reactive oxygen species in failing cardiac myocytes. Circulation 121:1606-1613

Kolmakova EV, Haller ST, Kennedy DJ, Isachkina AN, Budny GV, Frolova EV, Piecha G, Nikitina ER, Malhotra D, Fedorova OV, Shapiro JI, Bagrov AY (2011) Endogenous cardiotonic steroids in chronic renal failure. Nephrol Dial Transplant 26:2912-2919

Komiyama Y, Dong XH, Nishimura N, Masaki H, Yoshika M, Masuda M, Takahashi H (2005) A novel endogenous digitalis, telocinobufagin, exhibits elevated plasma levels in patients with terminal renal failure. Clin Biochem 38:36-45

Körner A, Eklöf AC, Celsi G, Aperia A (1994) Increased renal metabolism in diabetes. Mechanism and functional implications . Diabetes 43:629-633

Kosiborod M, Cavender MA, Fu AZ, Wilding JP, Khunti K, Holl RW, Norhammar A, Birkeland KI, Jorgensen ME, Thuresson M, Arya N, Bodegard J, Hammar N, Fenici P, C-R Study Group (2017) Lower risk of heart failure and death in patients initiated on sodium-glucose cotransporter- 2 inhibitors versus other glucose-lowering drugs: the CVD-real study (comparative effectiveness of cardiovascular outcomes in new users of sodium-glucose cotransporter-2 inhibitors). Circulation 136:249-259

Kreisberg JI (1982) Insulin requirement for contraction of cultured rat glomerular mesangial cells in response to angiotensin II: possible role for insulin in modulating glomerular hemodynamics. Proc Natl Acad Sci USA 79:4190-4192

Kuriyama S, Nakamura K, Kaguchi Y, Tomonari H, Tokutome G, Hashimoto T, Sakai O (1992) Increased Na-K transport in glomerular mesangial cell membrane from spontaneously hypertensive rats. Nephron 60:448-452

Kusaka H, Koibuchi N, Hasegawa Y, Ogawa H, Kim-Mitsuyama S (2016) Empagliflozin lessened cardiac injury and reduced visceral adipocyte hypertrophy in prediabetic rats with metabolic syndrome. Cardiovasc Diabetol 15:157

Lamb JF, McCall D (1971) Uptake of (3H)ouabain and Na pump turnover rates in monolayer cultures of Girardi heart cells. J Physiol 213:57P-58P

Lamb JF, Ogden P (1982) Internalization of ouabain and replacement of sodium pumps in the plasma membranes of HeLa cells following block with cardiac glycosides. Q J Exp Physiol 67:105-119

Lambert R, Srodulski S, Peng X, Margulies KB, Despa F, Despa S (2015) Intracellular $\mathrm{Na}+$ concentration $([\mathrm{Na}+] \mathrm{i})$ is elevated in diabetic hearts due to enhanced $\mathrm{Na}+-$ glucose cotransport. J Am Heart Assoc 4:e02183

Laredo J, Shah JR, Lu ZR, Hamilton BP, Hamlyn JM (1997) Angiotensin II stimulates secretion of endogenous ouabain from bovine adrenocortical cells via angiotensin type 2 receptors. Hypertension 29:401-407

Lee YJ, Lee YJ, Han HJ (2007) Regulatory mechanisms of $\mathrm{Na(+)/}$ glucose cotransporters in renal proximal tubule cells. Kidney Int 72:S27-35

Li Z, Xie Z (2009) The Na/K-ATPase/Src complex and cardiotonic steroid-activated protein kinase cascades. Pflugers Arch 457:635-644

Li Z, Cai T, Tian J, Xie JX, Zhao X, Liu L, Shapiro JI, Xie Z (2009) NaKtide, a Na/K-ATPase-derived peptide Src inhibitor, antagonizes ouabain-activated signal transduction in cultured cells. J Biol Chem 284:21066-21076

Li J, Khodus GR, Kruusmägi M, Kamali-Zare P, Liu XL, Eklöf AC, Zelenin S, Brismar H, Aperia A (2010) Ouabain protects against adverse developmental programming of the kidney. Nat Commun $1: 42$

Li Z, Zhang Z, Xie JX, Li X, Tian J, Cai T, Cui H, Ding H, Shapiro JI, Xie Z (2011) Na/K-ATPase mimetic pNaKtide peptide inhibits the growth of human cancer cells. J Biol Chem 286:32394-32403

Li XC, Soleimani M, Zhu D, Rubera I, Tauc M, Zheng X, Zhang J, Chen X, Zhuo JL (2018) Proximal tubule-specific deletion of the NHE3 $(\mathrm{Na}(+) / \mathrm{H}(+)$ exchanger 3$)$ promotes the pressure-natriuresis Response and Lowers blood pressure in Mice. Hypertension 72:1328-1336

Li C, Zhang J, Xue M, Li X, Han F, Liu X, Xu L, Lu Y, Cheng Y, Li T, Yu X, Sun B, Chen L (2019) SGLT2 inhibition with empagliflozin attenuates myocardial oxidative stress and fibrosis in diabetic mice heart. Cardiovasc Diabetol 18:15

Lim VG, Bell RM, Arjun S, Kolatsi-Joannou M, Long DA, Yellon DM (2019) SGLT2 inhibitor, canagliflozin, attenuates myocardial infarction in the diabetic and nondiabetic heart. JACC Basic Transl Sci 4:15-26

Lin B, Koibuchi N, Hasegawa Y, Sueta D, Toyama K, Uekawa K, Ma M, Nakagawa T, Kusaka H, Kim-Mitsuyama S (2014) Glycemic control with empagliflozin, a novel selective SGLT2 inhibitor, ameliorates cardiovascular injury and cognitive dysfunction in obese and type 2 diabetic mice. Cardiovasc Diabetol 13:148

List JF, Whaley JM (2011) Glucose dynamics and mechanistic implications of SGLT2 inhibitors in animals and humans. Kidney Int 79:20-27

Liu J, Shapiro JI (2007) Regulation of sodium pump endocytosis by cardiotonic steroids: Molecular mechanisms and physiological implications. Pathophysiology 14:171-181

Liu J, Tian J, Haas M, Shapiro JI, Askari A, Xie Z (2000) Ouabain interaction with cardiac $\mathrm{Na}+\mathrm{K}+$-ATPase initiates signal cascades independent of changes in intracellular $\mathrm{Na}+$ and $\mathrm{Ca} 2+$ concentrations. J Biol Chem 275:27838-27844

Liu J, Kesiry R, Periyasamy SM, Malhotra D, Xie Z, Shapiro JI (2004) Ouabain induces endocytosis of plasmalemmal Na/K-ATPase in LLC-PK 1 cells by a clathrin-dependent mechanism. Kidney Int 66:227-241

Liu J, Liang M, Liu L, Malhotra D, Xie Z, Shapiro JI (2005) Ouabaininduced endocytosis of the plasmalemmal Na/K-ATPase in LLCPK1 cells requires caveolin-1. Kidney Int 67:1844-1854

Liu L, Li J, Liu J, Yuan Z, Pierre SV, Qu W, Zhao X, Xie Z (2006) Involvement of $\mathrm{Na}+/ \mathrm{K}+-\mathrm{ATPase}$ in hydrogen peroxideinduced hypertrophy in cardiac myocytes. Free Radic Biol Med 41:1548-1556 
Liu J, Yan Y, Liu L, Xie Z, Malhotra D, Joe B, Shapiro JI (2011) Impairment of $\mathrm{Na} / \mathrm{K}-\mathrm{ATPase}$ signaling in renal proximal tubule contributes to Dahl salt-sensitive hypertension. J Biol Chem 286:22806-22813

Liu C, Bai Y, Chen Y, Wang Y, Sottejeau Y, Liu L, Li X, Lingrel JB, Malhotra D, Cooper CJ, Shapiro JI, Xie ZJ, Tian J (2012) Reduction of $\mathrm{Na} / \mathrm{K}$-ATPase potentiates marinobufagenininduced cardiac dysfunction and myocyte apoptosis. J Biol Chem 287:16390-16398

Liu J, Tian J, Chaudhry M, Maxwell K, Yan Y, Wang X, Shah PT, Khawaja AA, Martin R, Robinette TJ, El-Hamdani A, Dodrill MW, Sodhi K, Drummond CA, Haller ST, Kennedy DJ, Abraham NG, Xie Z, Shapiro JI (2016a) Attenuation of Na/K-ATPase mediated oxidant AMPLIFICATION with pNaKtide ameliorates experimental uremic cardiomyopathy. Sci Rep 6:34592

Liu L, Wu J, Kennedy DJ (2016b) Regulation of cardiac remodeling by cardiac $\mathrm{Na}(+) / \mathrm{K}(+)$-ATPase Isoforms. Front Physiol 7:382

Liu J, Nie Y, Chaudhry M, Bai F, Chuang J, Sodhi K, Shapiro JI (2020) The Redox-Sensitive Na/K-ATPase Signaling in Uremic Cardiomyopathy. Int J Mol Sci 21:1256

Lopaschuk GD, Verma S (2020) Mechanisms of cardiovascular benefits of sodium glucose co-transporter 2 (SGLT2) inhibitors: A Stateof-the-Art review. JACC Basic Transl Sci 5:632-644

Loreaux EL, Kaul B, Lorenz JN, Lingrel JB (2008) Ouabain-Sensitive alpha1 Na, K-ATPase enhances natriuretic response to saline load. J Am Soc Nephrol 19:1947-1954

Lucchesi PA, Sweadner KJ (1991) Postnatal changes in Na, K-ATPase isoform expression in rat cardiac ventricle. Conservation of biphasic ouabain affinity. J Biol Chem 266:9327-9331

Lytvyn Y, Bjornstad P, Udell JA, Lovshin JA, Cherney DZI (2017) Sodium glucose cotransporter-2 inhibition in heart failure. Circulation 136:1643-1658

Maki T, Maeno S, Maeda Y, Yamato M, Sonoda N, Ogawa Y, Wakisaka M, Inoguchi T (2019a) Amelioration of diabetic nephropathy by SGLT2 inhibitors independent of its glucose-lowering effect: A possible role of SGLT2 in mesangial cells. Sci Rep 9:4703

Mancini SJ, Boyd D, Katwan OJ, Strembitska A, Almabrouk TA, Kennedy S, Palmer TM, Salt IP (2018) Canagliflozin inhibits interleukin-1 $\beta$-stimulated cytokine and chemokine secretion in vascular endothelial cells by AMP-activated protein kinasedependent and -independent mechanisms. Sci Rep 8:5276

Manunta P, Stella P, Rivera R, Ciurlino D, Cusi D, Ferrandi M, Hamlyn JM, Bianchi G (1999) Left ventricular mass, stroke volume, and ouabain-like factor in essential hypertension. Hypertension $34: 450-456$

Manunta P, Hamilton BP, Hamlyn JM (2006a) Salt intake and depletion increase circulating levels of endogenous ouabain in normal men. Am J Physiol Regul Integr Comp Physiol 290:R553-R559

Manunta P, Hamilton BP, Hamlyn JM (2006b) Salt intake and depletion increase circulating levels of endogenous ouabain in normal men. Am J Physiol 290:R553-R559

Mason RM, Wahab NA (2003) Extracellular matrix metabolism in diabetic nephropathy. J Am Soc Nephrol 14:1358-1373

Mazer CD, Hare GMT, Connelly PW, Gilbert RE, Shehata N, Quan A, Teoh H, Leiter LA, Zinman B, Jüni P, Zuo F, Mistry N, Thorpe KE, Goldenberg RM, Yan AT, Connelly KA, Verma S (2020) Effect of empagliflozin on erythropoietin levels, iron stores, and red blood cell morphology in patients with type 2 diabetes mellitus and coronary artery disease. Circulation 141:704-707

Meng XM, Nikolic-Paterson DJ, Lan HY (2016) TGF- $\beta$ : the master regulator of fibrosis. Nat Rev Nephrol 12:325-338

Miyata KN, Zhao S, Wu CH, Lo CS, Ghosh A, Chenier I, Filep JG, Ingelfinger JR, Zhang SL, Chan JSD (2020) Comparison of the effects of insulin and SGLT2 inhibitor on the Renal
Renin-Angiotensin system in type 1 diabetes mice. Diabetes Res Clin Pract 162:108107

Moseley AE, Cougnon MH, Grupp IL, El Schultz J, Lingrel JB (2004) Attenuation of cardiac contractility in Na, K-ATPase alpha1 isoform-deficient hearts under reduced calcium conditions. J Mol Cell Cardiol 37:913-919

Mosenzon O, Wiviott SD, Cahn A, Rozenberg A, Yanuv I, Goodrich EL, Murphy SA, Heerspink HJL, Zelniker TA, Dwyer JP, Bhatt DL, Leiter LA, McGuire DK, Wilding JPH, Kato ET, GauseNilsson IAM, Fredriksson M, Johansson PA, Langkilde AM, Sabatine MS, Raz I (2019) Effects of dapagliflozin on development and progression of kidney disease in patients with type 2 diabetes: an analysis from the DECLARE-TIMI 58 randomised trial. Lancet Diabetes Endocrinol 7:606-617

Müller-Ehmsen J, Nickel J, Zobel C, Hirsch I, Bölck B, Brixius K, Schwinger RH (2003) Longer term effects of ouabain on the contractility of rat isolated cardiomyocytes and on the expression of $\mathrm{Ca}$ and Na regulating proteins. Basic Res Cardiol 98:90-96

Munzel T, Gori T, Bruno RM, Taddei S (2010) Is oxidative stress a therapeutic target in cardiovascular disease? Eur Heart $\mathbf{J}$ 31:2741-2748

Murdoch CE, Zhang M, Cave AC, Shah AM (2006) NADPH oxidasedependent redox signalling in cardiac hypertrophy, remodelling and failure. Cardiovasc Res 71:208-215

Nakamura N, Matsui T, Ishibashi Y, Yamagishi S (2015) Insulin stimulates SGLT2-mediated tubular glucose absorption via oxidative stress generation. Diabetol Metab Syndr 7:48

Neal B, Perkovic V, Mahaffey KW, de Zeeuw D, Fulcher G, Erondu N, Shaw W, Law G, Desai M, Matthews DR (2017a) Canagliflozin and cardiovascular and renal events in type 2 diabetes. N Engl J Med 377:644-657

Neal B, Perkovic V, Mahaffey KW, de Zeeuw D, Fulcher G, Erondu N, Shaw W, Law G, Desai M, Matthews DR, Group CPC (2017b) Canagliflozin and Cardiovascular and Renal Events in Type 2 Diabetes. N Engl J Med 377:644-657

Nikolic M, Zivkovic V, Jovic JJ, Sretenovic J, Davidovic G, Simovic S, Djokovic D, Muric N, Bolevich S, Jakovljevic V (2021) SGLT2 inhibitors: a focus on cardiac benefits and potential mechanisms. Heart Fail Rev. https://doi.org/10.1007/s10741-021-10079-9

Nilsson LM, Zhang L, Bondar A, Svensson D, Wernerson A, Brismar H, Scott L, Aperia A (2019) Prompt apoptotic response to high glucose in SGLT-expressing renal cells. Am J Physiol Renal Physiol 316:F1078-f1089

Norgaard A, Bagger JP, Bjerregaard P, Baandrup U, Kjeldsen K, Thomsen PE (1988) Relation of left ventricular function and $\mathrm{Na}$, K-pump concentration in suspected idiopathic dilated cardiomyopathy. Am J Cardiol 61:1312-1315

Onishi A, Fu Y, Darshi M, Crespo-Masip M, Huang W, Song P, Patel R, Kim YC, Nespoux J, Freeman B, Soleimani M, Thomson S, Sharma K, Vallon V (2019) Effect of renal tubule-specific knockdown of the $\mathrm{Na}+/ \mathrm{H}+$ exchanger NHE3 in Akita diabetic mice. Am J Physiol Ren Physiol 317:F419-F434

Onishi A, Fu Y, Patel R, Darshi M, Crespo-Masip M, Huang W, Song P, Freeman B, Kim YC, Soleimani M, Sharma K, Thomson SC, Vallon $\mathrm{V}(2020)$ A role for tubular $\mathrm{Na}(+) / \mathrm{H}(+)$ exchanger NHE3 in the natriuretic effect of the SGLT2 inhibitor empagliflozin. Am J Physiol Renal Physiol 319:F712-f728

Oshima M, Neuen BL, Jardine MJ, Bakris G, Edwards R, Levin A, Mahaffey KW, Neal B, Pollock C, Rosenthal N, Wada T, Wheeler DC, Perkovic V, Heerspink HJL (2020) Effects of canagliflozin on anaemia in patients with type 2 diabetes and chronic kidney disease: a post-hoc analysis from the CREDENCE trial. Lancet Diabetes Endocrinol 8:903-914

Packer M (2017) Activation and inhibition of sodium-hydrogen exchanger is a mechanism that links the pathophysiology and 
treatment of diabetes mellitus with that of heart failure. Circulation 136:1548-1559

Packer M, Anker SD, Butler J, Filippatos G, Pocock SJ, Carson P, Januzzi J, Verma S, Tsutsui H, Brueckmann M, Jamal W, Kimura K, Schnee J, Zeller C, Cotton D, Bocchi E, Böhm M, Choi D-J, Chopra V, Chuquiure E, Giannetti N, Janssens S, Zhang J, Gonzalez Juanatey JR, Kaul S, Brunner-La Rocca H-P, Merkely B, Nicholls SJ, Perrone S, Pina I, Ponikowski P, Sattar N, Senni M, Seronde M-F, Spinar J, Squire I, Taddei S, Wanner C, Zannad F (2020) Cardiovascular and renal outcomes with empagliflozin in heart failure. N Engl J Med 383:1413-1424

Panchapakesan U, Pegg K, Gross S, Komala MG, Mudaliar H, Forbes J, Pollock C, Mather A (2013) Effects of SGLT2 inhibition in human kidney proximal tubular cells-renoprotection in diabetic nephropathy? PLoS ONE 8:e54442

Patel AB, Mistry K, Verma A (2021) DAPA-CKD: significant victory for CKD with or without diabetes. Trends Endocrinol Metab. https://doi.org/10.1016/j.tem.2021.02.007

Periyasamy SM, Liu J, Tanta F, Kabak B, Wakefield B, Malhotra D, Kennedy DJ, Nadoor A, Fedorova OV, Gunning W, Xie Z, Bagrov AY, Shapiro JI (2005) Salt loading induces redistribution of the plasmalemmal $\mathrm{Na} / \mathrm{K}-\mathrm{ATP}$ ase in proximal tubule cells. Kidney Int 67:1868-1877

Perkovic V, Jardine MJ, Neal B, Bompoint S, Heerspink HJL, Charytan DM, Edwards R, Agarwal R, Bakris G, Bull S, Cannon CP, Capuano G, Chu P-L, de Zeeuw D, Greene T, Levin A, Pollock C, Wheeler DC, Yavin Y, Zhang H, Zinman B, Meininger G, Brenner BM, Mahaffey KW (2019) Canagliflozin and renal outcomes in type 2 diabetes and nephropathy. N Engl J Med 380:2295-2306

Petrykiv S, Sjöström CD, Greasley PJ, Xu J, Persson F, Heerspink HJL (2017) Differential effects of dapagliflozin on cardiovascular risk factors at varying degrees of renal function. Clin J Am Soc Nephrol 12:751-759

Pickering RJ, Rosado CJ, Sharma A, Buksh S, Tate M, de Haan JB (2018) Recent novel approaches to limit oxidative stress and inflammation in diabetic complications. Clin Transl Immunol 7:e1016

Prasad V, Lorenz JN, Miller ML, Vairamani K, Nieman ML, Wang Y, Shull GE (2013) Loss of NHE1 activity leads to reduced oxidative stress in heart and mitigates high-fat diet-induced myocardial stress. J Mol Cell Cardiol 65:33-42

Pratt RD, Brickman CR, Cottrill CL, Shapiro JI, Liu J (2018) The $\mathrm{Na}$ /K-ATPase Signaling: From Specific Ligands to General Reactive Oxygen Species. Int J Mol Sci 19:2600

Pratt RD, Brickman C, Nawab A, Cottrill C, Snoad B, Lakhani HV, Jelcick A, Henderson B, Bhardwaj NN, Sanabria JR, Liu J, Xie Z, Abraham NG, Shapiro JI, Sodhi K (2019) The adipocyte $\mathrm{Na} / \mathrm{K}$-ATPase oxidant amplification loop is the central regulator of western diet-induced obesity and associated comorbidities. Sci Rep 9:7927

Rahmoune H, Thompson PW, Ward JM, Smith CD, Hong G, Brown $\mathrm{J}$ (2005) Glucose transporters in human renal proximal tubular cells isolated from the urine of patients with non-insulindependent diabetes. Diabetes 54:3427-3434

Ramesh S, Wildey GM, Howe PH (2009) Transforming growth factor beta (TGFbeta)-induced apoptosis: the rise \& fall of Bim. Cell Cycle 8:11-17

Ronco C, Haapio M, House AA, Anavekar N, Bellomo R (2008) Cardiorenal syndrome. J Am Coll Cardiol 52:1527-1539

Rossi G, Manunta P, Hamlyn JM, Pavan E, De Toni R, Semplicini A, Pessina AC (1995) Immunoreactive endogenous ouabain in primary aldosteronism and essential hypertension: relationship with plasma renin, aldosterone and blood pressure levels. J Hypertens 13:1181-1191
Sakata Y, Masuyama T, Yamamoto K, Nishikawa N, Yamamoto H, Kondo H, Ono K, Otsu K, Kuzuya T, Miwa T, Takeda H, Miyamoto E, Hori M (2000) Calcineurin inhibitor attenuates left ventricular hypertrophy, leading to prevention of heart failure in hypertensive rats. Circulation 102:2269-2275

Sanchez G, Nguyen AN, Timmerberg B, Tash JS, Blanco G (2006) The Na, K-ATPase alpha4 isoform from humans has distinct enzymatic properties and is important for sperm motility. Mol Hum Reprod 12:565-576

Santos DSd, Polidoro JZ, Borges-Júnior FA, Girardi ACC (2020) Cardioprotection conferred by sodium-glucose cotransporter 2 inhibitors: a renal proximal tubule perspective. Am J Physiol Cell Physiol 318:C328-C336

Sattar N, McGuire DK (2018) Pathways to cardiorenal complications in type 2 diabetes mellitus: a need to rethink. Circulation 138:7-9

Scheen AJ (2019) Beneficial effects of SGLT2 inhibitors on fatty liver in type 2 diabetes: a common comorbidity associated with severe complications. Diabetes Metab 45:213-223

Schena FP, Gesualdo L (2005) Pathogenetic mechanisms of diabetic nephropathy. J Am Soc Nephrol 16(Suppl 1):S30-S33

Schmidt TA, Allen PD, Colucci WS, Marsh JD, Kjeldsen K (1993) No adaptation to digitalization as evaluated by digitalis receptor (Na, K-ATPase) quantification in explanted hearts from donors without heart disease and from digitalized recipients with end-stage heart failure. Am J Cardiol 71:110-114

Scholtes RA, Muskiet MHA, van Baar MJB, Hesp AC, Greasley PJ, Karlsson C, Hammarstedt A, Arya N, van Raalte DH, Heerspink HJL (2021) Natriuretic effect of two weeks of dapagliflozin treatment in patients with type 2 diabetes and preserved kidney function during standardized sodium intake: results of the DAPASALT trial. Diabetes Care 44:440-447

Schoner W (2002) Endogenous cardiac glycosides, a new class of steroid hormones. Eur J Biochem 269:2440-2448

Schoner W, Scheiner-Bobis G (2007a) Endogenous and exogenous cardiac glycosides and their mechanisms of action. Am J Cardiovasc Drugs 7:173-189

Schoner W, Scheiner-Bobis G (2007b) Endogenous and exogenous cardiac glycosides: their roles in hypertension, salt metabolism, and cell growth. Am J Physiol Cell Physiol 293:C509-C536

Schoner W, Scheiner-Bobis G (2008) Role of endogenous cardiotonic steroids in sodium homeostasis. Nephrol Dial Transplant 23:2723-2729

Schork A, Saynisch J, Vosseler A, Jaghutriz BA, Heyne N, Peter A, Häring HU, Stefan N, Fritsche A, Artunc F (2019) Effect of SGLT2 inhibitors on body composition, fluid status and reninangiotensin-aldosterone system in type 2 diabetes: a prospective study using bioimpedance spectroscopy. Cardiovasc Diabetol $18: 46$

Schwinger RH, Bundgaard H, Muller-Ehmsen J, Kjeldsen K (2003) The Na, K-ATPase in the failing human heart. Cardiovasc Res 57:913-920

Seddon M, Looi YH, Shah AM (2007) Oxidative stress and redox signalling in cardiac hypertrophy and heart failure. Heart 93:903-907

Semb SO, Lunde PK, Holt E, Tonnessen T, Christensen G, Sejersted OM (1998) Reduced myocardial Na+, K(+)-pump capacity in congestive heart failure following myocardial infarction in rats. J Mol Cell Cardiol 30:1311-1328

Sen T, Heerspink HJL (2021) A kidney perspective on the mechanism of action of sodium glucose co-transporter 2 inhibitors. Cell Metab. https://doi.org/10.1016/j.cmet.2021.02.016

Shaikh A (2017) A practical approach to hypertension management in diabetes. Diabetes Ther 8:981-989 
Shamraj OI, Melvin D, Lingrel JB (1991) Expression of Na, K-ATPase isoforms in human heart. Biochem Biophys Res Commun 179:1434-1440

Shapiro JI, Tian J (2011) Signaling through the Na/K-ATPase: implications for cardiac fibrosis. Am J Physiol Circ Physiol 300:H29-30

Shirakawa K, Sano M (2020) Sodium-glucose Co-transporter 2 inhibitors correct metabolic maladaptation of proximal tubular epithelial cells in high-glucose conditions. Int J Mol Sci. https://doi. org/10.3390/ijms 21207676

Skou JC (1957) The influence of some cations on an adenosine triphosphatase from peripheral nerves. Biochim Biophys Acta 23:394-401

Skoumal R, Szokodi I, Aro J, Foldes G, Gooz M, Seres L, Sarman B, Lako-Futo Z, Papp L, Vuolteenaho O, Leppaluoto J, DeChatel R, Ruskoaho H, Toth M (2007) Involvement of endogenous ouabain-like compound in the cardiac hypertrophic process in vivo. Life Sci 80:1303-1310

Sodhi K, Srikanthan K, Goguet-Rubio P, Nichols A, Mallick A, Nawab A, Martin R, Shah PT, Chaudhry M, Sigdel S, El-Hamdani M, Liu J, Xie Z, Abraham NG, Shapiro JI (2017) pNaKtide attenuates steatohepatitis and atherosclerosis by blocking $\mathrm{Na} / \mathrm{K}$ ATPase/ROS amplification in C57B16 and ApoE knockout mice fed a western diet. Sci Rep 7:193

Sodhi K, Nichols A, Mallick A, Klug RL, Liu J, Wang X, Srikanthan K, Goguet-Rubio P, Nawab A, Pratt R, Lilly MN, Sanabria JR, Xie Z, Abraham NG, Shapiro JI (2018) The Na/K-ATPase Oxidant Amplification Loop Regulates Aging. Sci Rep 8:9721

Sodhi K, Wang X, Chaudhry MA, Lakhani HV, Zehra M, Pratt R, Nawab A, Cottrill CL, Snoad B, Bai F, Denvir J, Liu J, Sanabria JR, Xie Z, Abraham NG, Shapiro JI (2020) Central role for adipocyte $\mathrm{Na}$, K-ATPase oxidant amplification loop in the pathogenesis of experimental uremic cardiomyopathy. J Am Soc Nephrol 31:1746-1760

Stark Casagrande S, Fradkin JE, Saydah SH, Rust KF, Cowie CC (2013) The prevalence of meeting A1C, blood pressure, and LDL goals among people with diabetes, 1988-2010. Diabetes Care 36:2271-2279

Sweadner KJ (1989) Isozymes of the Na+/K+-ATPase. Biochim Biophys Acta 988:185-220

Swift F, Birkeland JA, Tovsrud N, Enger UH, Aronsen JM, Louch WE, Sjaastad I, Sejersted OM (2008) Altered $\mathrm{Na}+/ \mathrm{Ca} 2+$-exchanger activity due to downregulation of $\mathrm{Na}^{+} / \mathrm{K}^{+}$-ATPase alpha2-isoform in heart failure. Cardiovasc Res 78:71-78

Tentolouris A, Vlachakis P, Tzeravini E, Eleftheriadou I, Tentolouris N (2019) SGLT2 inhibitors: a review of their antidiabetic and cardioprotective effects. Int J Environ Res Public Health. https:// doi.org/10.3390/ijerph16162965

Terami N, Ogawa D, Tachibana H, Hatanaka T, Wada J, Nakatsuka A, Eguchi J, Horiguchi CS, Nishii N, Yamada H, Takei K, Makino $\mathrm{H}$ (2014) Long-term treatment with the sodium glucose cotransporter 2 inhibitor, dapagliflozin, ameliorates glucose homeostasis and diabetic nephropathy in db/db mice. PLoS ONE 9:e100777

Thomson SC, Vallon V (2019) Renal effects of sodium-glucose cotransporter inhibitors. Am J Cardiol 124(Suppl 1):S28-s35

Tian J, Liu J, Garlid KD, Shapiro JI, Xie Z (2003) Involvement of mitogen-activated protein kinases and reactive oxygen species in the inotropic action of ouabain on cardiac myocytes. A potential role for mitochondrial K(ATP) channels. Mol Cell Biochem 242:181-187

Tikkanen I, Chilton R, Johansen OE (2016) Potential role of sodium glucose cotransporter 2 inhibitors in the treatment of hypertension. Curr Opin Nephrol Hypertens 25:81-86

Touyz RM (2004) Reactive oxygen species, vascular oxidative stress, and redox signaling in hypertension: what is the clinical significance? Hypertension 44:248-252
Toyama T, Neuen BL, Jun M, Ohkuma T, Neal B, Jardine MJ, Heerspink HL, Wong MG, Ninomiya T, Wada T, Perkovic V (2019) Effect of SGLT2 inhibitors on cardiovascular, renal and safety outcomes in patients with type 2 diabetes mellitus and chronic kidney disease: A systematic review and meta-analysis. Diabetes Obes Metab 21:1237-1250

Umino H, Hasegawa K, Minakuchi H, Muraoka H, Kawaguchi T, Kanda T, Tokuyama H, Wakino S, Itoh H (2018) High basolateral glucose increases sodium-glucose cotransporter 2 and reduces sirtuin- 1 in renal tubules through glucose transporter-2 detection. Sci Rep 8:6791

Uthman L, Baartscheer A, Bleijlevens B, Schumacher CA, Fiolet JWT, Koeman A, Jancev M, Hollmann MW, Weber NC, Coronel R, Zuurbier CJ (2018a) Class effects of SGLT2 inhibitors in mouse cardiomyocytes and hearts: inhibition of $\mathrm{Na}(+) / \mathrm{H}(+)$ exchanger, lowering of cytosolic $\mathrm{Na}(+)$ and vasodilation. Diabetologia 61:722-726

Uthman L, Baartscheer A, Schumacher CA, Fiolet JWT, Kuschma MC, Hollmann MW, Coronel R, Weber NC, Zuurbier CJ (2018b) Direct Cardiac Actions of Sodium Glucose Cotransporter 2 Inhibitors Target Pathogenic Mechanisms Underlying Heart Failure in Diabetic Patients. Front Physiol 9:1575

Vallon V, Thomson SC (2017) Targeting renal glucose reabsorption to treat hyperglycaemia: the pleiotropic effects of SGLT2 inhibition. Diabetologia 60:215-225

Vallon V, Platt KA, Cunard R, Schroth J, Whaley J, Thomson SC, Koepsell H, Rieg T (2011) SGLT2 mediates glucose reabsorption in the early proximal tubule. J Am Soc Nephrol 22:104-112

van Bommel EJM, Lytvyn Y, Perkins BA, Soleymanlou N, Fagan NM, Koitka-Weber A, Joles JA, Cherney DZI, van Raalte DH (2020) Renal hemodynamic effects of sodium-glucose cotransporter 2 inhibitors in hyperfiltering people with type 1 diabetes and people with type 2 diabetes and normal kidney function. Kidney Int 97:631-635

van der Pol A, van Gilst WH, Voors AA, van der Meer P (2019) Treating oxidative stress in heart failure: past, present and future. Eur J Heart Fail 21:425-435

Vasilakou D, Karagiannis T, Athanasiadou E, Mainou M, Liakos A, Bekiari E, Sarigianni M, Matthews DR, Tsapas A (2013) Sodium-glucose cotransporter 2 inhibitors for type 2 diabetes: a systematic review and meta-analysis. Ann Intern Med 159:262-274

Vestri S, Okamoto MM, de Freitas HS, Aparecida Dos Santos R, Nunes MT, Morimatsu M, Heimann JC, Machado UF (2001) Changes in sodium or glucose filtration rate modulate expression of glucose transporters in renal proximal tubular cells of rat. J Membr Biol 182:105-112

Wakabayashi S, Hisamitsu T, Nakamura TY (2013) Regulation of the cardiac $\mathrm{Na}^{+} / \mathrm{H}^{+}$exchanger in health and disease. J Mol Cell Cardiol 61:68-76

Wakisaka M, Nagao T (2017) Sodium glucose cotransporter 2 in mesangial cells and retinal pericytes and its implications for diabetic nephropathy and retinopathy. Glycobiology 27:691-695

Wakisaka M, Nagao T, Yoshinari M (2016) Sodium glucose cotransporter 2 (SGLT2) plays as a physiological glucose sensor and regulates cellular contractility in rat mesangial cells. PLoS ONE 11:e0151585

Wang X, Shapiro JI (2019) Evolving concepts in the pathogenesis of uraemic cardiomyopathy. Nat Rev Nephrol 15:159-175

Wang X, Chaudhry MA, Nie Y, Xie Z, Shapiro JI, Liu J (2017) A Mouse 5/6th Nephrectomy Model That Induces Experimental Uremic Cardiomyopathy. JoVE. https://doi.org/10.3791/55825

Wang J, Wang X, Gao Y, Lin Z, Chen J, Gigantelli J, Shapiro JI, Xie Z, Pierre SV (2020) Stress signal regulation by Na/K-ATPase as a new approach to promote physiological revascularization 
in a mouse model of ischemic retinopathy. Invest Ophthalmol vis Sci 61:9

Wanner C, Inzucchi SE, Lachin JM, Fitchett D, von Eynatten M, Mattheus M, Johansen OE, Woerle HJ, Broedl UC, Zinman B (2016) Empagliflozin and progression of kidney disease in Type 2 diabetes. N Engl J Med 375:323-334

Wanner C, Heerspink HJL, Zinman B, Inzucchi SE, Koitka-Weber A, Mattheus M, Hantel S, Woerle H-J, Broedl UC, von Eynatten M, Groop P-H (2018) Empagliflozin and kidney function decline in patients with type 2 diabetes: a slope analysis from the EMPAREG OUTCOME Trial. J Am Soc Nephrol 29:2755-2769

Wheeler DC, Stefánsson BV, Jongs N, Chertow GM, Greene T, Hou FF, McMurray JJV, Correa-Rotter R, Rossing P, Toto RD, Sjöström CD, Langkilde AM, Heerspink HJL (2021) Effects of dapagliflozin on major adverse kidney and cardiovascular events in patients with diabetic and non-diabetic chronic kidney disease: a prespecified analysis from the DAPA-CKD trial. Lancet Diabetes Endocrinol 9:22-31

Wilding JP, Charpentier G, Hollander P, Gonzalez-Galvez G, Mathieu C, Vercruysse F, Usiskin K, Law G, Black S, Canovatchel W, Meininger G (2013) Efficacy and safety of canagliflozin in patients with type 2 diabetes mellitus inadequately controlled with metformin and sulphonylurea: a randomised trial. Int J Clin Pract 67:1267-1282

Wilson AJ, Gill EK, Abudalo RA, Edgar KS, Watson CJ, Grieve DJ (2018) Reactive oxygen species signalling in the diabetic heart: emerging prospect for therapeutic targeting. Heart 104:293-299

Wiviott SD, Raz I, Bonaca MP, Mosenzon O, Kato ET, Cahn A, Silverman MG, Zelniker TA, Kuder JF, Murphy SA, Bhatt DL, Leiter LA, McGuire DK, Wilding JPH, Ruff CT, Gause-Nilsson IAM, Fredriksson M, Johansson PA, Langkilde A-M, Sabatine MS (2018) Dapagliflozin and cardiovascular outcomes in type 2 diabetes. N Engl J Med 380:347-357

Wong CM, Cheema AK, Zhang L, Suzuki YJ (2008) Protein carbonylation as a novel mechanism in redox signaling. Circ Res 102:310-318

Wong CM, Marcocci L, Liu L, Suzuki YJ (2010) Cell signaling by protein carbonylation and decarbonylation. Antioxid Redox Signal 12:393-404

Wright EM, Hirayama BA, Loo DF (2007) Active sugar transport in health and disease. J Intern Med 261:32-43

Wright EM, Loo DD, Hirayama BA (2011) Biology of human sodium glucose transporters. Physiol Rev 91:733-794

Wu XY, Luo AY, Zhou YR, Ren JH (2014) N-acetylcysteine reduces oxidative stress, nuclear factor- $\mathrm{\kappa B}$ activity and cardiomyocyte apoptosis in heart failure. Mol Med Rep 10:615-624

Xie Z, Cai T (2003) Na+-K+-ATPase-mediated signal transduction: from protein interaction to cellular function. Mol Interv 3:157-168

Xie Z, Kometiani P, Liu J, Li J, Shapiro JI, Askari A (1999) Intracellular reactive oxygen species mediate the linkage of $\mathrm{Na}+\mathrm{K}+-$ ATPase to hypertrophy and its marker genes in cardiac myocytes. J Biol Chem 274:19323-19328

Yan Y, Shapiro AP, Haller S, Katragadda V, Liu L, Tian J, Basrur V, Malhotra D, Xie ZJ, Abraham NG, Shapiro JI, Liu J (2013) Involvement of reactive oxygen species in a feed-forward mechanism of $\mathrm{Na} / \mathrm{K}$-ATPase-mediated signaling transduction. J Biol Chem 288:34249-34258
Yan Y, Wang J, Chaudhry MA, Nie Y, Sun S, Carmon J, Shah PT, Bai F, Pratt R, Brickman C, Sodhi K, Kim JH, Pierre S, Malhotra D, Rankin GO, Xie ZJ, Shapiro JI, Liu J (2019) Metabolic syndrome and salt-sensitive hypertension in polygenic obese TALLYHO/ JngJ mice: role of Na/K-ATPase signaling. Int J Mol Sci. https:// doi.org/10.3390/ijms20143495

Yatime L, Buch-Pedersen MJ, Musgaard M, Morth JP, Lund Winther AM, Pedersen BP, Olesen C, Andersen JP, Vilsen B, Schiott B, Palmgren MG, Moller JV, Nissen P, Fedosova N (2009) P-type ATPases as drug targets: tools for medicine and science. Biochim Biophys Acta 1787:207-220

Yatime L, Laursen M, Morth JP, Esmann M, Nissen P, Fedosova NU (2011) Structural insights into the high affinity binding of cardiotonic steroids to the $\mathrm{Na}^{+}, \mathrm{K}^{+}$-ATPase. J Struct Biol 174:296-306

Ye Y, Bajaj M, Yang HC, Perez-Polo JR, Birnbaum Y (2017) SGLT-2 Inhibition with dapagliflozin reduces the activation of the Nlrp3/ ASC inflammasome and attenuates the development of diabetic cardiomyopathy in mice with type 2 diabetes. further augmentation of the effects with saxagliptin, a DPP4 inhibitor. Cardiovasc Drugs Ther 31:119-132

Ye N, Jardine MJ, Oshima M, Hockham C, Heerspink HJL, Agarwal R, Bakris G, Schutte AE, Arnott C, Chang TI, Górriz JL, Cannon CP, Charytan DM, Zeeuw Dd, Levin A, Mahaffey KW, Neal B, Pollock C, Wheeler DC, Tanna GLD, Cheng H, Perkovic V, Neuen BL (2021) Blood pressure effects of canagliflozin and clinical outcomes in type 2 diabetes and chronic kidney disease: insights from the CREDENCE trial. Circulation 143:1735

Zhang L, Staehr C, Zeng F, Bouzinova EV, Matchkov VV (2019a) The Na, K-ATPase in vascular smooth muscle cells. Curr Top Membr 83:151-175

Zhang Y, Wei W, Shilova V, Petrashevskaya NN, Zernetkina VI, Grigorova YN, Marshall CA, Fenner RC, Lehrmann E, Wood WH, Becker KG, Lakatta EG, Bagrov AY, Fedorova OV (2019b) Monoclonal antibody to marinobufagenin downregulates TGF $\beta$ profibrotic signaling in left ventricle and kidney and reduces tissue remodeling in salt-sensitive hypertension. J Am Heart Assoc 8:e012138

Zhao QD, Viswanadhapalli S, Williams P, Shi Q, Tan C, Yi X, Bhandari B, Abboud HE (2015) NADPH oxidase 4 induces cardiac fibrosis and hypertrophy through activating Akt/mTOR and NFKB signaling pathways. Circulation 131:643-655

Zinman B, Wanner C, Lachin JM, Fitchett D, Bluhmki E, Hantel S, Mattheus M, Devins T, Johansen OE, Woerle HJ, Broedl UC, Inzucchi SE (2015a) Empagliflozin, cardiovascular outcomes, and mortality in type 2 diabetes. N Engl J Med 373:2117-2128

Zinman B, Wanner C, Lachin JM, Fitchett D, Bluhmki E, Hantel S, Mattheus M, Devins T, Johansen OE, Woerle HJ, Broedl UC, Inzucchi SE, Investigators E-RO (2015c) Empagliflozin, cardiovascular outcomes, and mortality in type 2 diabetes. $\mathrm{N}$ Engl $\mathrm{J}$ Med 3:2117-2128

Publisher's Note Springer Nature remains neutral with regard to jurisdictional claims in published maps and institutional affiliations. 